\title{
An Interdisciplinary Framework for Understanding and Cultivating Law Student Enthusiasm
}

Emily Zimmerman

Follow this and additional works at: https://via.library.depaul.edu/law-review

\section{Recommended Citation}

Emily Zimmerman, An Interdisciplinary Framework for Understanding and Cultivating Law Student Enthusiasm, 58 DePaul L. Rev. 851 (2009)

Available at: https://via.library.depaul.edu/law-review/vol58/iss4/4

This Article is brought to you for free and open access by the College of Law at Digital Commons@DePaul. It has been accepted for inclusion in DePaul Law Review by an authorized editor of Digital Commons@DePaul. For more information, please contact digitalservices@depaul.edu. 


\title{
AN INTERDISCIPLINARY FRAMEWORK FOR UNDERSTANDING AND CULTIVATING LAW STUDENT ENTHUSIASM
}

\author{
Emily Zimmerman*
}

\section{INTRODUCTION}

Anecdotal evidence abounds about the loss of enthusiasm experienced by law students. ${ }^{1}$ Scholars also note this loss of enthusiasm and the demoralization of law students that occurs during their time in law school. ${ }^{2}$ However, although the loss of enthusiasm is frequently noted

* Associate Professor of Law, Drexel University Earle Mack School of Law. J.D., Yale Law School; A.B., Bryn Mawr College. The author thanks Alex Geisinger, Terry Jean Seligmann, Roy Stuckey, Gerry Hess, Dan Filler, Susan Brooks, Kathy Stanchi, Barbara Glesner Fines, David Cohen, Brian Foley, and Jay Wussow for their thoughtful feedback. The author also thanks her research assistants, Lonn Selbst, Sarah McKeown, Michael Keesler, and Michael Kuehn. The author thanks current and former law librarians at Drexel University Earle Mack School of Law, including Benjamin Carlson, Peter Egler, Keith Berthrong, and Karen Schneiderman. The author thanks Larry Krieger and Ann Renninger for discussing and sharing their work with the author. The author appreciates having had the opportunity to discuss some of the ideas developed in this Article at workshops with faculty and students at Drexel University Earle Mack School of Law and during a presentation at the Humanizing Legal Education Symposium at Washburn University School of Law, as well as during other conversations with her colleagues.

1. See, e.g., William M. Sullivan, Anne Colby, Judith Welch Wegner, Lloyd Bond \& Lee S. Shulman, Educating Lawyers: Preparation for the Profession of Law 77 (2007) [hereinafter CARNEGIE RePORT] (recognizing "anecdotal lore, long circulated in law schools, that many students ... gradually become disengaged from their course work").

2. See Lawrence S. Krieger, Institutional Denial About the Dark Side of Law School, and Fresh Empirical Guidance for Constructively Breaking the Silence, 52 J. LEGAL Educ. 112, 113-14 (2002) [hereinafter Institutional Denial] (reviewing the literature regarding the negative effects of law school on law students, including students' loss of enthusiasm over the course of the first year of law school); see also Lawrence S. Krieger, Human Nature As a New Guiding Philosophy for Legal Education and the Profession, 47 WAShBuRn L.J. 247, 263 (2008) [hereinafter Human Nature] (noting "the common observations of initial enthusiasm followed by increasing disengagement of law students"); Gerald F. Hess, Heads and Hearts: The Teaching and Learning Environment in Law School, 52 J. Legal Educ. 75, 75 (2002) [hereinafter Heads and Hearts] (noting law students' loss of "excitement and [positive] expectations"); Carnegie REPORT, supra note 1, at 139 (noting "the slackening of interest among students in the third year [of law school]"); Roy Stuckey et al., Best Practices for Legal Education: A Vision and A Roadmap 140-41 (2007) [hereinafter Best PRACTICES] (noting law students' "boredom and loss of interest in learning" and that "by graduation [law students] have lost much of [their] passion for justice and enthusiasm for helping other people'" (quoting Deborah Maranville, Infusing Passion and Context into the Traditional Law Curriculum Through Experiential Learning, 51 J. Legal Educ. 51, 51 (2001))); Mitu Gulati, Richard Sander \& Robert Sockloskie, The 
as a problem for legal education, little has been done to systematically analyze law student enthusiasm. The existing literature neither defines nor provides a foundation of theory and research for understanding "law student enthusiasm" and its significance in legal education.

Moreover, while one of the problems with legal education may be that it causes law student enthusiasm to diminish, a more pressing problem with legal education may be that it does not cultivate law students' enthusiasm for law study-the very work in which law students are immersed in law school. ${ }^{3}$ Law school is a demanding, intense experience. Law students may experience distress in law school, particularly during the first year of law school, because they are required to dedicate themselves to work, law study, for which they do not have enthusiasm. ${ }^{4}$ The lack of law student enthusiasm could, therefore, be a cause of law student distress in law school, in addition to a symptom of law student distress in law school. ${ }^{5}$

Whether students lose enthusiasm in law school or do not come to law school with enthusiasm, the lack of law student enthusiasm is a

Happy Charade: An Empirical Examination of the Third Year of Law School, 51 J. LeGAL EDuc. 235, 246 (2001) (noting "[t]he profound disengagement of third-year students"); Kennon M. Sheldon \& Lawrence S. Krieger, Does Legal Education Have Undermining Effects on Law Students? Evaluating Changes in Motivation, Values, and Well-Being, 22 BeHAv. ScI. \& L. 261, 262-63 (2004) [hereinafter Does Legal Education] (reviewing the literature describing law students' declining mental health in law school and critiquing legal education); Leah M. Christensen, Going Back to Kindergarten: Considering the Application of Waldorf Education Principles to Legal Education, 40 Suffolk U. L. Rev. 315, 325-26 (2007) ("First-year law students enter law school with excitement for the practice of law. Professors [who teach first-year law students] have an opportunity to teach ... students when their enthusiasm and respect for the law is high." (footnote omitted)); Gary A. Negin, The Effects of Test Frequency in a First-Year Torts Course, $31 \mathrm{~J}$. Legal Educ. 673, 673 (1981) (noting that during the first year of law school, "enthusiastic students adjust to the demands of a new discipline and intense competition"); Note, Making Docile Lawyers: An Essay on the Pacification of Law Students, 111 HARv. L. Rev. 2027, 2034, 2041 n.59, 2042 (1998) [hereinafter Making Docile Lawyers] (noting law students' loss of enthusiasm and "disengage[ment] from the law school").

3. Frequently, when articles mention law students' loss of enthusiasm, it is presented as an indication of problems with legal education-the result of law students' experience in law school, particularly during the first year of law school. See, e.g., Institutional Denial, supra note 2; Making Docile Lawyers, supra note 2.

4. See Derek C. Bok, A Flawed System of Law Practice and Training, 33 J. Legal Educ. 570, 584 (1983). As Bok states:

[L]aw schools have traditionally been the refuge of able, ambitious college seniors who cannot think of anything else they want to do. With such lukewarm beginnings, it is not surprising that many students tire of their studies and grow unwilling after their first Id. year to prepare their coursework or participate in class discussions.

5. See Stephen B. Shanfield \& G. Andrew H. Benjamin, Psychiatric Distress in Law Students, 35 J. Legal Educ. 65, 71 (1985) ("[Law students'] lack of commitment to law can be a factor [contributing to their] distress ...."). 
significant concern for legal educators. First, the lack of law student enthusiasm diminishes the quality of law students' experience in law school and may be a source of law students' distress in law school. ${ }^{6}$ Second, the lack of law student enthusiasm may impede law students' learning in law school. ${ }^{7}$ Third, the lack of law student enthusiasm may extend into law students' professional lives after law school, resulting in lawyers who lack enthusiasm for and a commitment to law practice. ${ }^{8}$ Because of the serious consequences of law students' lack of enthusiasm, one of the priorities of legal education should be to cultivate law students' enthusiasm for law study. ${ }^{9}$

6. See Human Nature, supra note 2, at 263; Shanfield \& Benjamin, supra note 5, at 71.

7. See Carnegie Report, supra note 1, at 27 ("In order to become expert in a profession, making good grades with minimal effort has to give way to a complete involvement with learning new ways of thinking, performing, and understanding oneself.").

8. See id. at 146 ("The kind of personal maturity that graduates need in order to practice law with integrity and a sense of purpose requires not only skills but qualities such as compassion, respectfulness, and commitment."); id. at 160-61 ("[O]ne essential goal of professional schools must be to form practitioners who are aware of what it takes to become competent in their chosen domain and to equip them with the reflective capacity and motivation to pursue genuine expertise.").

9. Just as law students might experience distress in law school because they are immersed in work (law study) for which they do not have enthusiasm, practicing lawyers might experience distress because they are immersed in work (law practice) for which they do not have enthusiasm. Some of the most prominent recent critiques of legal education have focused on the importance of law school as the training ground for lawyers. CARNEGIE RePORT, supra note 1; BEST PRACTICEs, supra note 2; see also B.A. Glesner, Fear and Loathing in the Law Schools, 23 ConN. L. REV. 627, 641 (1991) ("Law school socializes lay persons into the legal profession."); Martin E.P. Seligman, Paul R. Verkuil \& Terry H. Kang, Why Lawyers Are Unhappy, 23 Cardozo L. REv. 33, 53 (2001) ("[Law schools] are the entry point to the profession and help shape the system."). These and other critiques have noted not only law students' distress in law school but also the distress of practicing lawyers, whose distress may well impact not only themselves and their families but also their clients. See, e.g., CARnegie Report, supra note 1, at 127 (noting "the growing sense of demoralization in legal practice"); id. at 136 (noting "troubling declines in public esteem for the [legal] profession and attorneys' apparently growing dissatisfaction with their work"); id. at 137 (noting "a loss of calling or sense of purpose among lawyers"); see also Seligman et al., supra, at 38 ("Unhappy lawyers . . can also injure their clients by failing to provide adequate representation."). Indeed, there is a persistent concern with both the high rates of depression and substance abuse among lawyers and also the lack of professionalism that is associated with the practice of law. See, e.g., Best PRACTICEs, supra note 2, at 90 ("Lawyers suffer higher rates of depression, anxiety, and other mental illness, suicide, divorce, alcoholism and drug abuse, and poor physical health than the general population or other occupations."). Therefore, in addition to cultivating law students' enthusiasm for law study, an additional goal of law school should be to cultivate law students' enthusiasm for law practice. See Bok, supra note 4, at 584 (urging law professors to "motivate their students" to want to become members of the legal profession to counter "the striking lack of professional commitment displayed by many [law] students"); Seligman et al., supra, at 39 ("Law schools are themselves a potential breeding ground for lawyer demoralization and that makes them . . candidates for reform."). This Article focuses on law student enthusiasm for law study and ways in which law schools can cultivate law students' enthusiasm for law study while students are in law school, although the research discussed in this Article could also be applied to law school's cultivation of law student enthusiasm for law practice. 
To discuss meaningful ways to cultivate law student enthusiasm, we must better understand "law student enthusiasm." This Article establishes "the enthusiasm paradigm": a new framework for understanding and cultivating law student enthusiasm. Drawing on psychology theory and research, this Article defines "law student enthusiasm" as law student interest for law study and vitality associated with law study. ${ }^{10}$ This Article examines some of the existing research regarding interest and vitality that informs an understanding of law student enthusiasm. ${ }^{11}$ This Article reviews recent examinations of legal education, ${ }^{12}$ explains how the enthusiasm paradigm adds to recent examinations of legal education, ${ }^{13}$ and recommends that the cultivation of law student enthusiasm become a priority of legal education. ${ }^{14}$ The Article then applies psychology theory and research regarding interest and vitality to legal education, examining particular aspects of legal education that warrant reexamination through the lens of the enthusiasm paradigm. ${ }^{15}$ Using this interdisciplinary focus, the Article proposes a number of specific ways in which legal education may better cultivate law students' enthusiasm for law study. ${ }^{16}$

10. Recent scholarship has focused both on defining terms used in examining legal education and applying psychology to legal education and law students' experience in law school. See Human Nature, supra note 2, at 260-61 (defining "humanizing" as used in "humanizing legal education"); id. at 264 (noting "the need for attention to the psychological dynamics at work in law students"); Bonita London, Geraldine Downey \& Shauna Mace, Psychological Theories of Educational Engagement: A Multi-Method Approach to Studying Individual Engagement and Institutional Change, 60 VAND. L. REV. 455, 456 (2007) (defining law student "engagement" and suggesting that research regarding legal education "be informed by theoretical models and experimental methodologies used in the field of social psychology"). However, even when identical terms are used in the context of legal education, they are not necessarily defined in the same way. Compare London et al., supra, at 456 (defining law student "engagement" as "not only ... the academic investment, motivation, and commitment that students demonstrate within their institution (both in and out of the classroom context), but also ... the psychological connection, comfort, and sense of belonging that students feel toward their institution, their peers, professors and administrators"), with Indiana University Center fOR POSTSECONDARY Research, Law School Survey of Student Engagement, LSSSE 2007: Invitation to Participate 3 (2007) (defining "engagement" as "the combination of time and energy students devote to educationally purposeful activities").

11. See infra notes $22-132$ and accompanying text.

12. See infra notes 141-208 and accompanying text. Specifically, this Section of the Article focuses on the Carnegie Report and the empirical research of Kennon Sheldon and Lawrence Krieger. See CARnegie Report, supra note 1; Does Legal Educaition, supra note 2; Kennon M. Sheldon \& Lawrence S. Krieger, Understanding the Negative Effects of Legal Education on Law Students: A Longitudinal Test of Self-Determination Theory, 33 Personaltry \& Soc. Psychol. BuLL. 883 (2007) [hereinafter Understanding the Negative Effects].

13. See infra notes 209-224 and accompanying text.

14. See infra notes $133-140$ and accompanying text.

15. See infra notes $225-311$ and accompanying text.

16. See infra notes $225-311$ and accompanying text. 


\section{The Challenge of Defining "Law Student Enthusiasm"}

Critiques of legal education frequently note that law students' enthusiasm declines in law school. ${ }^{17}$ However, these critiques do not explicitly define what is meant by "enthusiasm" or analyze the components of any such definition. ${ }^{18}$ To better understand how legal education can cultivate law student enthusiasm, it is necessary to first reach an understanding of what law student enthusiasm is. However, this is easier said than done as there is not a commonly accepted definition of law student enthusiasm in the legal literature. ${ }^{19}$ Moreover, even outside of the context of legal education, "enthusiasm," when used, is not always defined, and, when it is defined, it is not always defined consistently. For example, one researcher defines enthusiasm as the outward "manifestation of energy," 20 while another researcher

17. See, e.g., Institutional Denial, supra note 2, at 113-14; Human Nature, supra note 2, at 263, 272; Making Docile Lawyers, supra note 2, at 2034.

18. See Institutional Denial, supra note 2; Human Nature, supra note 2; Making Docile Lawyers, supra note 2.

19. There are particular words used in some of the literature that may convey enthusiasm in its colloquial sense. In discussing the role of legal education, one author defines "passion" as "boundless enthusiasm." Deborah Maranville, Infusing Passion and Context into the Traditional Law Curriculum Through Experiential Learning, 51 J. Legal EduC. 51, 53 (2001) ("Imparting passion for the law-passion in the sense of boundless enthusiasm-may be the most critical aspect of legal education ....."); see also id. at 51 n.1. Gerry Hess compares the excitement and eagerness of his students when he was a second-grade teacher to that of his first-year law students. Heads and Hearts, supra note 2, at 75; see also id. at 111 (describing Hess's goal of maintaining students' "eagerness to learn" with respect to both his law students and second-grade students). However, a common definition and conceptual framework is needed in order to better understand and analyze law student enthusiasm. Moreover, these descriptions do not uniformly take into account the specific enthusiasm for law study that should be a component of law student enthusiasm.

20. Brian C. Patrick, Jennifer Hisley \& Toni Kempler, "What's Everybody So Excited About?": The Effects of Teacher Enthusiasm on Student Intrinsic Motivation and Vitality, $68 \mathrm{~J}$. EXPERIMENTAL EduC. 217, 220 (2000) (describing enthusiasm as "a behavioral manifestation of energy"); see also Frederick J. Brigham, Thomas E. Scruggs \& Margo A. Mastropieri, Teacher Enthusiasm in Learning Disabilities Classrooms: Effects on Learning and Behavior, 7 LEARNING Disabilities Res. \& Practice 68, 70 (1992). Brigham et al. assess teacher enthusiasm based almost exclusively on teachers' physical behavior:

(a) rapid, uplifting, varied vocal delivery; (b) dancing, wide open eyes; (c) frequent, demonstrative gestures; (d) varied, dramatic body movements; (e) varied, emotive facial expression; (f) selection of varied words; (g) ready, animated acceptance of ideas and feelings; and (h) exuberant over-all energy level.

Brigham et al., supra, at 70; accord Edward M. Bettencourt, Maxwell H. Gillett, Meredith Damien Fall \& Ray E. Hull, Effects of Teacher Enthusiasm Training on Student On-task Behavior and Achievement, 20 AM. Educ. Res. J. 435 passim (1983). Outward behaviors that can be perceived by students have also been described as ways that law teachers can demonstrate their enthusiasm. Best Practices, supra note 2, at 125; see also id. at 234 ("[When lecturing, law teachers should] [b]e enthusiastic, speak loudly and clearly so that everyone can hear, vary [their] tone of voice, and maintain eye contact with the audience."). 
defines enthusiasm as "morale." 21

However, when discussing enthusiasm in the context of law student enthusiasm for law study, neither energetic behavior nor morale adequately reflect what is meant by enthusiasm. A committed, engaged learner may not always outwardly manifest energy. Much of the study of law involves what might appear to be physically sedentary activities: thinking, reading, researching. Enthusiasm for law study is related less to the external display of energy, which is a function of an observer's perceptions of the law student, and more to the internal state of the law student himself or herself. "Morale" also does not seem to fully capture what is meant by law student enthusiasm. A law student who is enthusiastic about law study may not always have high "morale," but may persist with law study nonetheless. "Morale" may describe certain aspects of a law student's state of mind, but it does not necessarily capture a law student's desire to study the law or commitment to law study.

\section{Law Student Enthusiasm as a Combination OF INTEREST AND ViTALITY}

In order to define "law student enthusiasm"-so that we can better understand how to cultivate law student enthusiasm-it is necessary to look beyond references to "enthusiasm" in both law and psychology literature. In fact, there are two different constructs in psychology literature that, when combined, provide a meaningful definition of law

In recommending that law teachers "take delight in teaching," Best Practices notes the importance of teacher enthusiasm and states that teachers can "communicate [their] enthusiasm for teaching by expressly describing [their] interest in the subject and teaching and what energizes [them]." Id. at 125 . This instruction more closely reflects the enthusiasm paradigm for understanding and cultivating law student enthusiasm that will be discussed in detail in this Article. See also Heads and Hearts, supra note 2, at 82-83 (describing the "intellectual excitement" component of Joseph Lowman's "model of effective adult education" and noting that the adjectives commonly used to describe excellent teachers with respect to this component included, "enthusiastic, knowledgeable, [and] inspiring"); Bettencourt et al., supra, at 448. In noting the limitations of their research, Bettencourt et al. state:

[B]oth experiments can be criticized because their operationalization of teacher enthusiasm relied exclusively on variables relating to surface behavior. There also may be important internal processes in enthusiasm, as suggested by the word's etymological root (possessed or inspired by a god) and current usage (ardent zeal, interest, excitement about a cause or subject). Internal processes in enthusiastic behavior need to be conceptualized, measured, and correlated with the external indicators already identified.

Id.

21. Richard deCharms, Motivation Training and Academic Achievement, in Enhancing MOTIVATION 141, 141 (1976). 
student enthusiasm: interest ${ }^{22}$ and vitality. ${ }^{23}$ "Interest" captures law students' commitment to law study. ${ }^{24}$ "Vitality" captures law students' subjective feelings of energy regarding law study. ${ }^{25}$ Together, interest and vitality provide the components of a definition of law student enthusiasm and the means for gaining a better understanding of how law student enthusiasm for law study can be cultivated.

Interest and vitality together capture the attributes of law student enthusiasm. Vitality is a meaningful-and perhaps more intuitivecomponent of law student enthusiasm because vitality represents the subjective energy that an individual feels. ${ }^{26}$ Vitality alone, however, does not sufficiently define law student enthusiasm because vitality does not capture a law student's particular interest for law study, nor does vitality capture the dynamic nature of a law student's interest for law study. Interest, conceptualized as being made up of both knowledge about a particular subject or activity and value for that subject or activity, ${ }^{27}$ captures the subject-specific nature of law student enthusiasm. The four-phase model of interest development, discussed below, ${ }^{28}$ is particularly salient because it recognizes different levels of interest and identifies characteristics of learners at different levels of interest. ${ }^{29}$ In addition, the four-phase model of interest development

22. See Suzanne Hidi \& K. Ann Renninger, The Four-Phase Model of Interest Development, 41 Educ. Psychologist 111 (2006) [hereinafter The Four-Phase Model of Interest Development].

23. See Richard M. Ryan \& Christina Frederick, On Energy, Personality, and Health: Subjective Vitality as a Dynamic Reflection of Well-Being, 65 J. Personality 529 (1997); Richard M. Ryan \& Edward L. Deci, From Ego Depletion to Vitality: Theory and Findings Concerning the Facilitation of Energy Available to the Self, 2 Soc. \& Personaltry Psychol. Compass 702 (2008).

24. See The Four-Phase Model of Interest Development, supra note 22, at 112 ("Interest as a motivational variable refers to the psychological state of engaging or the predisposition to reengage with particular classes of objects, events, or ideas over time.").

25. See Ryan \& Frederick, supra note 23, at 530.

26. Id. at 536 .

27. K. Ann Renninger, Individual Interest and Its Implications for Understanding Intrinsic Motivation, in InTRInsic and Extrinsic Motivation 373, 376 (Carol Sansone \& Judith M. Harackiewicz eds., 2000) [hereinafter Individual Interest]. The value component of individual interest includes value for the subject or activity itself and value for engaging with that subject or activity. Id. at 376, 378, 380. As Renninger states:

Value serves to maintain a person's attention to interest-related content, in turn leading to a deepened understanding, to more content-specific questions, and so on. Thus, the attention of a person is schooled both by individual interest and by the possibilities of particular contexts for extending and/or constraining its development. These include support to grow a particular individual interest, interaction with expert others, and tasks that permit use of individual interest as context.

Id. at $380-81$.

28. See infra notes 39-103 and accompanying text.

29. See, e.g., The Four-Phase Model of Interest Development, supra note 22; Rebecca L. Lipstein \& K. Ann Renninger, "Putting Things into Words": The Development of 12-15-Year Old 
reflects that interest is dynamic: interest can deepen or recede. ${ }^{30}$ Moreover, the characteristics of an individual with a well-developed individual interest are characteristics that are desirable in law students. ${ }^{31}$ For example, individuals with a well-developed individual interest identify with the topic of interest, desire feedback so that they can improve their performance, and are effective problem-solvers. ${ }^{32}$

The constructs of interest and vitality thus define law student enthusiasm and inform discussions about law student enthusiasm. A focus on how legal education can cultivate law student enthusiasm must address both the promotion of law students' interest for and vitality regarding law study. This Part examines theory and research regarding interest and vitality that inform an understanding of law student enthusiasm. ${ }^{33}$

\section{A. Interest}

Interest is a concept on which educators and educational psychologists have long focused. ${ }^{34}$ In the early twentieth century, for example, John Dewey highlighted the importance of interest to learning. ${ }^{35}$ Interest for Dewey meant that an individual had "identified ... with a certain course of action and with the objects or skills that are necessary to achieve a desired goal." 36 According to Dewey, interest and effort were related, as "[e]ffort involves the transformation of the present state in order to realize a goal." 37

Although the concept of interest is not new, the attention given to interest has increased tremendously in the last thirty years. ${ }^{38}$ The

Students' Interest for Writing, in WRITING AND Motrvation 113, 135 (Suzanne Hidi \& Pietro Boscolo eds., 2007) [hereinafter Putting Things into Words].

30. The Four-Phase Model of Interest Development, supra note 22, at 112.

31. See Putting Things Into Words, supra note 29, at 135; Individual Interest, supra note 27, at 377 .

32. Individual Interest, supra note 27 , at 377 . In this Article, the focus of an individual's interest is frequently referred to as the "topic" of interest. The focus of an individual's interest is also referred to as the "subject" or "activity" of interest.

33. See infra notes 34-132 and accompanying text.

34. See Arthur G. Wirth, John Dewey as Educator: His Design for Work in EducaTION (1894-1904) 92 (1966); see also Andreas Krapp, Suzanne Hidi \& K. Ann Renninger, Interest, Learning, and Development, in THE Role of INTEREST IN LEARNING AND Development 3-25 (Andreas Krapp, Suzanne Hidi \& K. Ann Renninger eds., 1992) [hereinafter Interest, Learning, and Development] (providing an overview of interest theories and research).

35. WIRTH, supra note 34 , at $92-99$.

36. Id. at 93.

37. Id.

38. See Suzanne Hidi, K. Ann Renninger \& Andreas Krapp, Interest, a Motivational Variable that Combines Affective and Cognitive Functioning, in Motivation, EMOTION, AND Cognition: Integrative Perspectives on Intellectual Functioning and Development 89, 92 (David Yun Dai \& Robert J. Sternberg eds., 2004). 
four-phase model of interest development proposed by Suzanne Hidi and $\mathrm{K}$. Ann Renninger is one recent theory of interest that is particularly relevant to the cultivation of law students' enthusiasm for law study. ${ }^{39}$ Hidi and Renninger have identified four phases of interest: "triggered situational interest," 40 "maintained situational interest," 41 "emerging individual interest," 42 and "well-developed individual interest." 43 According to Hidi and Renninger, interest develops as the individual interacts with his or her environment, and interest is dynamic: it can deepen over time or, conversely, diminish over time. ${ }^{44}$

The first phase of interest is "triggered situational interest."45 Triggered situational interest is interest that is stimulated by an individual's encounter with something in his or her environment that draws his or her attention. ${ }^{46}$ Triggered situational interest is superficial-the individual does not know much about the topic of interest, and the individual's interest may be short-lived. ${ }^{47}$

However, the individual's superficial interest may develop and deepen as the individual connects with the topic of interest and decides that he or she wants to learn more about the topic. This second phase of interest development is called "maintained situational interest."48 At the maintained situational interest phase, an individual needs external support to pursue the topic of interest. ${ }^{49}$ The individual has not yet internalized his or her interest and may not be able to pursue the topic independently. ${ }^{50}$ At the maintained situational inter-

39. The Four-Phase Model of Interest Development, supra note 22. The four-phase model of interest development "builds on and extends empirical studies of interest and learning." Id. at 111. In fact, there is a vast body of literature regarding different theories of interest and research regarding interest. See, e.g., id. at 111-13 (reviewing some of the literature regarding interest); see also id. at $111 \mathrm{n} .1$ (noting that Hidi and Renninger's four-phase model of interest development "extends and further details a three-phase model of interest on which [Hidi and Renninger] collaborated with [Andreas] Krapp").

40. Id. at 114 .

41. Id.

42. Id.

43. Id. at 115. Broadly defined:

Situational interest refers to focused attention and the affective reaction that is triggered in the moment by environmental stimuli, which may or may not last over time, whereas individual interest refers to a person's relatively enduring predisposition to reengage particular content over time as well as to the immediate psychological state when this predisposition has been activated.

Id. at 113 (citations omitted).

44. Id. at 112 .

45. Id. at 112,114 .

46. Id. at 114.

47. Id.

48. Id at $112,114$.

49. Id. at 114.

50. Id. 
est phase, the individual may not know enough about the topic of interest to formulate his or her own questions about the topic and independently discover the answers to his or her own questions. ${ }^{51}$

If the individual is supported in his or her developing interest, the individual may start to internalize that interest, progressing to the third phase of interest: "emerging individual interest." 52 At the emerging individual interest phase, an individual has both some knowledge about the topic of his or her interest and some value for that topic; "[b]ased on previous engagement, the student values the opportunity to reengage tasks related to his or her emerging individual interest and will opt to do these if given a choice." 53 An individual with an emerging individual interest will pursue a topic independently, generating "curiosity questions" 54 about the topic of interest and formulating ways to resolve those questions for himself or herself. ${ }^{55} \mathrm{At}$ the same time, an individual with an emerging individual interest may still need external support as he or she pursues the topic of his or her interest and "may need encouragement from others to persevere when confronted with difficulty." 56

The final, fourth stage of interest development is "well-developed individual interest." 57 An individual with a well-developed individual interest in a topic has internalized his or her interest in the topic. ${ }^{58}$ The individual will pursue the topic independently and will persevere with the topic in the face of difficulty. ${ }^{59}$ An individual with a welldeveloped individual interest will have "a relatively enduring predis-

51. Id. at $122-23$.

52. Id. at 112,114 .

53. Id. at $114-15$.

54. "Curiosity questions are the students' own questions (whether verbalized or not) about content that lead them to reflect, seek further understanding, and begin taking responsibility for their own learning." K. Ann Renninger \& Rebecca L. Lipstein, Come Si Sviluppa L'interesse Per La Scrittura: Cosa Vogliono Gli Studenti E Di Cosa Hannobisogno? [Developing Interest for Writing: What Do Students Want and What Do Students Need?], in ETA Evolutiva 65, 3 (Pietro Boscolo ed., 2006) [hereinafter Developing Interest for Writing]. The published version of this chapter is in Italian (as is the book in which the chapter is included). This author obtained an English-language version of this chapter from Ann Renninger, and the cites in this Article are to the English-language version of the chapter, which the author has on file.

55. The Four-Phase Model of Interest Development, supra note 22, at 115. According to the four-phase model of interest development, individuals with an emerging individual interest will generate their own questions about a topic. Id. Another researcher has suggested teaching students to ask questions in order to facilitate students' learning. Alison King, Inquiring Minds Really Do Want to Know: Using Questioning to Teach Critical Thinking, 22 TEACHING PsYCHOL. 13 (1995).

56. The Four-Phase Model of Interest Development, supra note 22, at 115.

57. Id. at 112,115 .

58. Id. at 115 .

59. Id. 
position to reengage with particular ... content over time" and will have "positive feelings [for the focus of interest], and more stored knowledge and more stored value for [that focus] than for other activity ....."60

Individuals need support along the continuum from triggered situational interest to well-developed individual interest. ${ }^{61}$ At any point along the way, an individual may lose interest in a topic or may regress from individual interest to situational interest if not provided with appropriate support. ${ }^{62}$ Moreover, developing situational interest is more a product of positive feelings associated with a topic than it is a product of an individual acquiring substantive knowledge about that topic. ${ }^{63}$ Positive feelings, however, can motivate an individual to persist with a topic of interest, causing the individual to gain substantive knowledge about that topic along the way. ${ }^{64}$ As an individual's interest develops and deepens, the individual's interest will be characterized by the acquisition of substantive knowledge. ${ }^{65}$ An individual's deepening, internalized interest in a topic may provide support for the individual's acquisition of substantive knowledge about that topic, enabling the individual to persist even when faced with frustration. ${ }^{66}$ However, if the individual faces frustration and negative feelings before his or her interest is internalized, the individual's interest will likely fail to develop beyond situational interest and may, in fact, diminish altogether. ${ }^{67}$

While individuals need external support to progress from one level of interest to the next, the type of support that an individual wants may depend on that individual's level of interest. ${ }^{68}$ In their research regarding students' interest for writing, ${ }^{69}$ Ann Renninger and Rebecca

60. Id.

61. Id. at 112 .

62. $I d$.

63. Id. at 114 .

64. Id.

65. Id. at $114-15$.

66. Id. at 115 .

67. Id. at 112; see also Putting Things into Words, supra note 29, at 136 (observing that as students' "confidence in their own knowledge and abilities increased, their interest for writing deepened").

68. Developing Interest for Writing, supra note 54, at 4.

69. Renninger and Lipstein administered a questionnaire to twelve- to fifteen-year-old students and interviewed students to try to identify these students' stage of interest for writing and the students' different perspectives regarding writing. Id.; Putting Things into Words, supra note 29; see also Rebecca L. Lipstein \& K. Ann Renninger, Interest for Writing: How Teachers Can Make a Difference, ENG. J., Mar. 2007, at 79 [hereinafter Interest for Writing]. Renninger and Lipstein found that students' interest for writing could be categorized according to Renninger and Hidi's four-phase model of interest development. Putting Things into Words, supra note 29, 
Lipstein found that students' receptivity to feedback and the type of feedback desired by students vary depending on a student's phase of interest for writing. ${ }^{70}$ Students with a triggered situational interest for writing want "concrete strategies that might alleviate some of their difficulties with writing."71 On the other hand, students with an emerging individual interest for writing tend to be resistant to feedback on their writing. ${ }^{72}$ These students "do not want to hear specific directives or questioning of their decision making" regarding their writing assignments. ${ }^{73}$ Students with an emerging individual interest in writing express confidence about their writing ability and identify

at 117-18, 121. Renninger and Lipstein described traits of students at each phase of interest for writing:

[S]tudents with only a triggered situational interest for writing (Phase 1) were students who had little knowledge about and little value for writing, but whose interest for writing could be triggered by the assignment of the "right" topic and/or feedback that recognized their ideas and offered them discrete suggestions for revision. Students identified as having a maintained situational interest (Phase 2) engaged writing as a set of rules. Like those in Phase 1, students in Phase 2 were assisted to begin thinking like writers if they were provided with topics that were of interest to them and/or supportive feedback. Students identified as having an emerging individual interest for writing (Phase 3) were students who had begun to think of themselves as writers and, probably because of this conception, did not want to be told what to do, nor were they interested in feedback from others that suggested that their writing might be differently developed or organized. Students identified as having a well-developed individual interest for writing (Phase 4) also thought of themselves as writers, but, unlike Phase 3 writers, these students actively sought feedback on their writing because they recognized that, through feedback, they could strengthen their ability to communicate their ideas to an audience.

Developing Interest for Writing, supra note 54, at 2-3.

70. Developing Interest for Writing, supra note 54, at 3.

71. Id. at 8 . These students may want concrete, specific feedback because this feedback is the most straightforward and easiest to implement. As Lipstein and Renninger note, students with a triggered situational interest for writing tend to be most concerned with the completion of a writing assignment (rather than with the process of writing or developing a mastery of writing). See Putting Things into Words, supra note 29, at 122 . These students may also "focus on grammar and other details" rather than broader issues with their writing. Id. at 120 . In addition, students with a triggered situational interest for writing may prefer more specific, concrete feedback because they may not know how to revise their writing to respond to more general, conceptual feedback. Id. at 123 .

72. Putting Things into Words, supra note 29, at 123.

73. Id. Although Renninger and Lipstein noted that resistance to feedback characterized students with an emerging individual interest for writing, in subsequent follow-up interviews with two of the students who were classified as having an emerging individual interest for writing, these students did express that feedback had some value "in building their feelings of self-efficacy as writers." Developing Interest for Writing, supra note 54, at 12 . However, for one of these students, "feedback" might have meant positive feedback that helped to promote his identity as a writer. $I d$. at 14 . One of the students also indicated that he did want feedback that would give him information about whether his writing was accomplishing his desired purpose. Id. at 12. Renninger and Lipstein note that this student appears to be transitioning from an emerging individual interest for writing to a well-developed individual interest for writing. Id. at 13 . 
themselves as writers. ${ }^{74}$ The combination of these students' resistance to feedback and identification of themselves as writers raises the possibility that these students are resistant to feedback for the very reason that it threatens their identity as writers. ${ }^{75}$ Once students are more secure with their identity as writers, however, students may become more receptive to feedback because it is less threatening to their writerly identity. In fact, Renninger and Lipstein found that students with a well-developed interest for writing sought and were receptive to feedback as a means to help them improve their writing. ${ }^{76}$ These students also recognized that their perceptions of their writing might differ from their audience's perceptions. ${ }^{77}$

Students in different phases of interest for writing not only have different views regarding feedback on their writing, but also have different goals and standards for their writing. Students with a triggered situational interest in writing are more focused on finishing their assignments than with developing a mastery of writing. ${ }^{78}$ Alternatively,

74. Developing Interest for Writing, supra note 54, at 2-3; see also Putting Things into Words, supra note 29, at 131 ("Students with an emerging individual interest for writing described themselves as writers and considered writing to be part of their identities.").

75. Developing Interest for Writing, supra note 54, at 2-3 ("Students identified as having an emerging individual interest for writing ... were students who had begun to think of themselves as writers and, probably because of this conception, did not want to be told what to do, nor were they interested in feedback from others that suggested that their writing might be differently developed or organized."); see also Putting Things into Words, supra note 29, at 132. As Lipstein and Renninger note:

Perhaps the most striking characteristic of students in this phase of [emerging individual] interest were [sic] their heightened feelings of self-efficacy. Students with an emerging individual interest for writing were very confident about their writing abilities, and some students even considered their own understanding of writing to exceed that of their teachers. ... Their dislike of peer conferences appeared to be linked to their heightened self-efficacy and investment in writing.

Id.

76. Developing Interest for Writing, supra note 54, at 3. Renninger and Lipstein also observe that other researchers "found that students with more developed interest are positioned to benefit most from feedback" and "that students with less developed interest for a content area are more receptive to positive feedback." Putting Things into Words, supra note 29, at 124 (citing Marian C. Fish \& Mary Alice White, The Effects of Verbal Reinforcement, Interest, and "Usable Performance Feedback" upon Task Performance, 47 J. Experimental Educ. 144 (1978-1979)). Other researchers have also noted individual variations in students' reactions to and preferences for feedback. See Pat Young, "I Might as Well Give Up": Self-Esteem and Mature Students' Feelings About Feedback on Assignments, 24 J. Further \& Higher Educ. 409 (2000).

77. Putting Things into Words, supra note 29, at 133-34.

78. Id at 120 ; see also id. at 126 (noting that students with a triggered situational interest for writing "said that they turned in papers to meet deadlines or because 'I have to;' [sic] however, they felt little investment in their work, and they had little will to improve"). Lipstein and Renninger also observed that students with a triggered situational interest for writing "reported almost no positive feelings or value for writing. They also expressed little confidence in their writing abilities and reported little to no engagement in writing activities outside school." $I d$. at 126. 
students with a triggered situational interest in writing may "focus on grammar and other details" rather than larger-scale aspects of their writing. ${ }^{79}$

Students beyond the triggered situational interest phase are concerned with doing a good job on their writing assignments. ${ }^{80}$ However, the standard by which students judge whether they have done a good job on their assignments may vary depending on the students' phase of interest for writing. ${ }^{81}$ Students with a maintained situational interest for writing tend to judge their performance on an assignment by their teacher's standards. ${ }^{82}$ Conversely, students with an emerging individual interest for writing tend to judge their performance by their own standards. ${ }^{83}$. These students tend to be quite focused on their own subjective perceptions of their writing and have difficulty seeing their writing from their audience's point of view (in addition to being resistant to critical feedback from their audience). ${ }^{84}$ Students with a well-developed individual interest in writing are able to judge their writing by both their own standards as well as the standards of others. ${ }^{85}$ These students recognize that their own perceptions of their writing might not be shared by their audience, and they are interested in their audience's perceptions and perspective. ${ }^{86}$

In addition to possessing different goals and standards for their writing, students also perceive writing as more or less "arduous" depending on their phase of interest for writing. ${ }^{87}$ Students with a trig-

79. Id. at 120 .

80. Id.

81. Id.

82. Id. Writing to please the teacher may not result in a student who feels "invested in ... writing." Id. at 130.

83. Id. at 120 .

84. Id. at 133. As Lipstein and Renninger state:

It seems that these students' passionate investment in their work prevented them from stepping back from a piece. While the students spoke of making revisions until they were personally satisfied, they did not seem concerned with objective standards. In addition, while their intentions to produce excellent writing were evident, they preferred to work "their own way," and did not necessarily employ strategies or suggestions from others.

Id.

85. Id. at 120.

86. Id.; see also id. at 135 ("[S]tudents with a well-developed individual interest for writing simultaneously demonstrated feelings of self-efficacy about their abilities to write and an awareness of their own shortcomings as writers."). Nonetheless, even students with a well-developed interest for writing, who want "critical feedback," may have a preference for the way in which such feedback is presented. Id. at 135 ("[S]tudents with a well-developed individual interest for writing ... prefer[red] to receive comments in a particular order: they wanted initial feedback to focus on their ideas and the paper's content, and they preferred to address more technical revisions in subsequent drafts.").

87. Id. at 123. 
gered situational interest for writing "perceive even small tasks as arduous." 88 On the other hand, students with an individual interest (both emerging and well-developed) "do not feel that the work they put into writing is arduous," even though they "expend a lot of effort" on their writing. ${ }^{89}$ Students with a maintained situational interest for writing "do not feel that writing takes an over whelming [sic] amount of work [and] do not invest more effort in writing than other school assignments." 90

Renninger and Lipstein have identified particular circumstances under which students' interest for writing can be developed. These circumstances promote students' security regarding their writing abilities and knowledge about writing. First, assigned work must match students' abilities; students must be assigned manageable challenges in light of their abilities. ${ }^{91}$ Renninger and Lipstein note that students with a triggered situational interest in writing "experience a lessening of interest when tasks exceed their level of mastery."92 Second, students want to "feel connected to their work" and want "their ideas to be respected and heard."93 Although giving students the freedom to choose their assignments might be one way to enable students to feel connected to their work, students may not actually want such freedom, depending on their phase of interest. ${ }^{94}$ Third, receiving positive response from an audience can help a student develop his or her interest for writing. ${ }^{95}$ However, a student's desire for critical feedback and

88. Id.
89. Id.
90. Id.
91. Developing Interest for Writing, supra note 54 , at 14 .
92. Id.; see also Edward L. Deci, The Relation of Interest to the Motivation of Behavior: A Self-Determination Theory Perspective, in The Role of INTEREST in Learning and DevelopMENT 43, 51 (K. Ann Renninger, Suzanne Hidi \& Andreas Krapp eds., 1992) ("[P]eople tend to freely seek and be interested in those activities or inputs that are optimally challenging, in other words, that are not fully mastered but are not so discrepant as to be frustrating."). Similarly, interest can also be diminished by feedback that seems too difficult to implement. Putting Things into Words, supra note 29 , at 136 ("[S]tudents who received feedback that was too discrepant (e.g., too abstract, or requiring a lot of work) often spoke of becoming less interested in writing as a result.").

93. Developing Interest for Writing, supra note 54, at 13.

94. Compare Putting Things into Words, supra note 29, at 129 ("In their interviews, students with a maintained situational interest for writing often expressed frustration with assignments that were too open-ended, claiming that such assignments made it difficult to figure out what the teacher wanted them to write about."), with id. at 133 ("[S]tudents with an emerging individual interest for writing typically indicated preferences for assignments that gave them as few restrictions as possible. Without a set genre or topic to limit them, these students enjoyed a sense of freedom and power."). Students with a triggered situational interest for writing also seemed to prefer being given freedom of choice, indicating that "'choice' and 'a good topic' made them want to write." Id. at 127.

95. Developing Interest for Writing, supra note 54, at 14. 
the type of critical feedback desired may depend on the student's phase of interest for writing. ${ }^{96}$ Fourth, helping students to develop a deeper understanding of writing may help students to develop a deeper interest for writing. ${ }^{97}$

Because students at different phases of interest vary in terms of their attitude toward writing and their desire for feedback, Renninger and Lipstein recommend that writing teachers recognize that students are at different phases of interest for writing. ${ }^{98}$ Indeed, how teachers teach may influence whether students develop an interest for writing and whether students' interest for writing increases or diminishes. ${ }^{99}$

96. Students with a triggered situational interest for writing "want to be heard; want comments that require few changes and feel manageable." Putting Things into Words, supra note 29, at 123. These students are "afraid of audience censure and being thought of as 'stupid." Id. Students with a maintained situational interest for writing "want to hear positive feedback and specific directions to improve their work." $I d$. These students "look to [the] teacher for standards of performance." $I d$. Students with an emerging individual interest for writing "want their ideas to be heard and have their work appreciated; want audience reactions that are open-ended; do not want to hear specific directives or questioning of their decision making." Id. As Lipstein and Renninger further explain:

While these students [with an emerging individual interest for writing] claimed during interviews that they desired feedback from their audiences, further discussion revealed that they only wanted comments of a reflective or laudatory nature. They did not like feedback that was specific and critical. They indicated that more prescriptive comments would infringe upon their own creative roles as authors and might go against their preferred ways of writing."

$I d$. at 132. Unlike students with an emerging individual interest for writing, students with a welldeveloped individual interest for writing "want their ideas to be heard and want honest feedback in any form, whether reactive or constructive criticism; prefer initial feedback on content, followed by feedback about technique." Id. at 123 (emphasis added).

97. Id. at 138 ("[T]eachers can support students to change their knowledge about writing, which may resonate with and/or result in changed affect and, in turn, lead to a deepened and/or developing interest for writing."). Although students at all phases of interest may express some theoretical understanding of writing, students with a triggered situational interest for writing may not apply this theoretical understanding to the reality of their own writing. Id. at 121. In addition, students may not fully appreciate the importance of both the author's and audience's perspective regarding a piece of writing and may, therefore, overly value one perspective over the other: a student with a maintained situational interest for writing may overvalue the audience's perspective (particularly the teacher's), while a student with an emerging individual interest for writing may overvalue the author's perspective. Id. at 129, 132-33.

98. Developing Interest for Writing, supra note 54, at 16.

99. Putting Things into Words, supra note 29, at 135 ("[T]he pedagogical choices a teacher makes (e.g., whether to assign work with peer partners, how to provide students with feedback, what types of assignments to give) have a critical influence on whether students are likely to develop and deepen their interest for writing."). As Lipstein and Renninger conclude:

Knowing more about the likely characteristics of writers in each phase of interest development should allow people who work with students on writing to better predict what might work and what complications might arise from their pedagogical decisions (e.g., choosing to use peer conferences or to provide students with feedback about grammar before acknowledging content). It is important for educators to recognize that interest for writing can develop, and that this process is likely to have stops and starts as students are supported to put things into words. 
Teaching to develop interest does not necessarily mean catering to a student's expressed preferences (for example, for a particular type of feedback), but rather taking into account both the "needs and preferences" of a student in determining how to support that student's learning. ${ }^{100}$

Interest is one component of law student enthusiasm. Interest captures the subject-specific nature of law student enthusiasm: enthusiasm for law study. Interest incorporates a student's positive feelings regarding, knowledge about, and value for law study. ${ }^{101}$ As will be explored further in later sections of this Article, ${ }^{102}$ the theory and research $^{103}$ regarding the four phases of interest inform an understand-

Id. at 140 .

100. Id. at 138. As Lipstein and Renninger write,

[Their research] underscores the importance of meeting students where they are as writers and also supporting them to stretch - recognizing that the stretch may not immediately support them to look like the student with a well-developed individual interest for writing, although that is a possibility. [Their research] further indicate[s] that simply matching instructional practices to students' current phases of interest is not likely to be effective pedagogy. Instead, it appears that pedagogy should be structured with an awareness of students' needs and preferences based on their current phase of interest for writing. This does not suggest that students should simply be told what they want to hear.... Rather, an awareness of students' current needs and preferences may provide teachers with information about how best to help students tackle the challenges that they face as writers.

Id. For example, just because a student with an emerging individual interest for writing is resistant to constructive criticism, does not mean that a teacher should not offer such feedback. See $i d$. at 137 (describing how an awareness of a student's phase of interest for writing could help a teacher give feedback more effectively to that student). A student with an emerging individual interest for writing may need guidance to better understand that one of the purposes of writing is communicating with an audience in order to help the student appreciate the importance of both audience feedback and viewing a piece of writing from the audience's perspective. $C f$. id. (stating that a teacher might need to help a student with an emerging individual interest for writing "increase[ ] the sophistication of his [or her] understanding of writing"). However, this guidance should reflect the teacher's appreciation of what the student is trying to accomplish with his or her writing, and present feedback in the context of helping the student better accomplish his or her purpose. Id.

If a student has a well-developed individual interest for writing, "[c]ontinued challenges in writing are essential for [that student's] interest to continue and deepen." Id. Positive feedback alone might not be sufficient to sustain a well-developed individual interest for writing. Id.

101. The Four-Phase Model of Interest Development, supra note 22, at 114.

102. See infra notes 118-140, 209-317 and accompanying text.

103. Although law students are older than the population of students on whom Renninger and Lipstein's research focuses, research regarding younger students has been used to inform recommended reforms of legal education and research regarding law students. See Developing Interest for Writing, supra note 54, at 4 (Renninger and Lipstein's research focuses on twelve- to fifteen-year-old students); Maranville, supra note 19, at 61 n.25; Leah M. Christensen, Predicting Law School Success: A Study of Goal Orientations, Academic Achievement, and the Declining Self-Efficacy of Our Law Students, 33 Law \& Psychol. Rev. (forthcoming 2009); Christensen, supra note 2. Regardless, additional research that investigates the application of the four-phase model of interest development to law students is needed. This author is conducting a research 
ing of law student enthusiasm for law study, the characteristics of students at different phases of interest for law study, and the ways in which legal education can cultivate students' enthusiasm for law study.

\section{B. Vitality}

Although interest is an important component of law student enthusiasm, interest alone does not fully describe law student enthusiasm because law student enthusiasm includes not only an interest in law study but also an excitement or energy for law study. The psychological construct of "subjective vitality" 104 captures the energetic component of enthusiasm. Thus, it is interest accompanied by vitality that most appropriately defines law student enthusiasm. ${ }^{105}$

study that investigates, inter alia, first-year law students' interest for law study. See infra note 216 and accompanying text.

Moreover, law students-particularly first-year law students-may, in fact, reflect characteristics of younger (more inexperienced) learners. Joni Larson, The Intersection of Andragogy and Distance Education: Handing over the Reins of Learning to Better Prepare Students for the Practice of Law, 9 T.M. Cooley J. Prac. \& Clinical L. 117, 128, 134 (2007) (stating that whether pedagogy or andragogy is the appropriate model "depend[s] on the situation of the learner, not the age of the learner," and concluding that pedagogy is the appropriate model to apply to firstyear law students). There is an extensive body of literature regarding the education of adults (andragogy) as distinguished from children (pedagogy). See Linda Morton, Janet Weinstein \& Mark Weinstein, Not Quite Grown Up: The Difficulty of Applying an Adult Education Model to Legal Externs, 5 CliniCAL L. Rev. 469, 473-79 (1999) (providing a brief overview of andragogy theory). Although law students are relatively older learners in terms of their chronological age, law students may not reflect all of the characteristics of adult learners as reflected in andragogy theory. See id. at 484-85, 519 (law students are not necessarily the type of "mature adults envisioned by adult education"); Frank S. Bloch, The Andragogical Basis of Clinical Legal Education, 35 VAND. L. REV. 321, 327 (1982) (applying andragogy to clinical legal education but recognizing that "law students are not necessarily typical of the adult learners that are the focus and subject of andragogical literature"); see also Nancy J. Soonpaa, Stress in Law Students: A Comparative Study of First-Year, Second-Year, and Third-Year Students, 36 ConN. L. Rev. 353, 357-59 (2004) (describing research regarding the developmental stages of graduate students as compared to adult developmental stages); Young, supra, note 76 , at 410 (discussing older students' status as adults and mentioning the work of one researcher who questions whether older students retain the characteristics of adults when they become students); $c f$. George D. Kuh \& Marilyn L. Thomas, The Use of Adult Development Theory with Graduate Students, J.C. STUDENT Personnel, Jan. 1983, at 12, 19 ("[A] student's age may not be a reliable indicator of the kinds of developmental issues facing the student."). But see Anthony S. Niedwiecki, Lawyers and Learning: $A$ Metacognitive Approach to Legal Education, 13 WIDENER L. Rev. 33, 47 (2006) (assuming that law students are adult learners); Michael Hunter Schwartz, Teaching Law by Design: How Learning Theory and Instructional Design Can Inform and Reform Law Teaching, 38 SAN Diego L. Rev. 347, 350 \& n.6 (2001) (using "andragogy" to refer to law school teaching because andragogy refers to the teaching of adults); cf. Kuh \& Thomas, supra, at 18-19 (reporting that, on the one hand, "adult developmental processes ... were found to be generally applicable to graduate students" and, on the other hand, "the responses of some of the younger students suggested behavior patterns more descriptive of older individuals").

104. Ryan \& Frederick, supra note 23 , at 529.

105. The psychology literature makes connections between vitality and enthusiasm. Definitions of vitality frequently reference "enthusiasm." See, e.g., id. at 530 (stating that vitality is "a 
As with interest, theory and research regarding vitality inform an understanding of law student enthusiasm and ways to cultivate law student enthusiasm. ${ }^{106}$ Vitality has been described as a "positive sense of aliveness and energy."107 Vitality refers to an individual's own sense of possessing energy or aliveness, rather than an observer's perception of another individual's level of energy. ${ }^{108}$ Moreover, vitality does not refer to energy that an individual expends on a particular activity, but rather energy that the individual subjectively feels he or she possesses. ${ }^{109}$ Subjective vitality has been correlated with measures of "both psychological and physical well-being."110

A relationship exists between vitality and the circumstances under which an individual engages in a particular activity. Researchers have found a significant difference between average changes in vitality for individuals engaging in a task autonomously versus non-autono-

specific psychological experience of possessing enthusiasm and spirit"); Glen A. Nix, Richard M. Ryan, John B. Manly \& Edward L. Deci, Revitalization Through Self-Regulation: The Effects of Autonomous and Controlled Motivation on Happiness and Vitality, 35 J. ExPERIMENTAL Soc. PsYCHOL. 266, 270 (1999) (describing enthusiasm as a "vitality-related affect[ ]"). In addition, researchers have investigated the correlation between teacher enthusiasm and student vitality. Patrick et al., supra note 20 , at 220 ("[E]nthusiasm and vitality share a remarkable conceptual similarity. Each construct captures an aspect of psychological energization, with enthusiasm representing a behavioral manifestation of energy and vitality being a subjective, experiential component."). However, when discussing law student enthusiasm, vitality alone does not fully encompass the definition of enthusiasm because it lacks the component of interest in law study.

106. See infra notes 118-140, 209-317 and accompanying text.

107. Ryan \& Frederick, supra note 23, at 530; see also id. at 531-33 (reviewing related theories).

108. Id. at 535. The construct of vitality has been analogized to the construct of "calm energy" which has been defined as "the relaxed possession of liveliness and vigor." Nix et al., supra note 105, at 268 (discussing the work of Robert E. Thayer); see also Robert E. Thayer \& Louis E. Moore, Reported Activation and Verbal Learning as a Function of Group Size (Social Facilitation) and Anxiety-Inducing Instructions, 88 J. Soc. PsychOL. 277, 279 (1972) (defining "general activation" as "lively, active, full-of-pep, energetic, peppy, vigorous, activated").

109. Ryan \& Frederick, supra note 23, at 536 ("Subjective vitality does not, therefore, refer to just any energy, but rather to energy felt to be one's own."); $i d$. at 559 (stating that subjective vitality is "a positive feeling of having personal energy").

Ryan and Frederick developed a seven-item questionnaire to measure an individual's vitality. Id. at 540. This questionnaire asks individuals to indicate their level of agreement with the following statements: "( $a$ ) 'I feel alive and vital'; (b) 'I don't feel very energetic' . . ; (c) 'Sometimes I feel so alive I just want to burst'; $(d)$ 'I have energy and spirit'; $(e)$ 'I look forward to each new day'; $(f)$ 'I nearly always feel alert and awake'; and $(g)$ 'I feel energized.'" Id. Subsequent researchers have suggested that eliminating the second item from the survey ("I don't feel very energetic") creates a better measure of vitality. Terence J. Bostic, Doris McGartland Rubio \& Mark Hood, $A$ Validation of the Subjective Vitality Scale Using Structural Equation Modeling, 52 SOC. IndiCATORS REs. 313, 317-19 (2000).

110. Ryan \& Frederick, supra note 23, at 559. Ryan and Frederick conducted a number of studies in different contexts to investigate the relationship between physical and psychological well-being and vitality. Id. at 539-57. 
mously. ${ }^{111}$ On average, the vitality of individuals who engaged in the task non-autonomously "dropped markedly." 112 Similarly, researchers have found that whether an individual feels an activity is internally or externally motivated can be related to that individual's reported vitality.113 In addition, individuals who perform a task

111. Nix et al., supra note 105 , at $274-76,280-81$. Nix et al. had individuals perform a card sorting exercise (the Wisconsin Card Sort). Id. at 274. The individuals, however, performed the exercise under two different conditions. Id. Some individuals were able to sort the cards autonomously-they decided for themselves how to sort each card based upon the criteria of the exercise. Id. Other individuals were specifically told how to sort each card and were told that how they were to sort the cards depended on how another person had sorted the cards. Id. Nix et al. used Ryan and Frederick's vitality scale to assess the individuals' vitality both before and after they performed the card sort exercise. Id. at 274-75. Nix et al. found that, on average, the individuals who were told how to sort the cards experienced a much greater drop in vitality than the individuals who were allowed to choose for themselves how to sort the cards. Id. at 275. Other researchers have also investigated the relationship between autonomy and vitality. Id. at 269 (reviewing the literature regarding the relationship between autonomy and vitality); Ryan \& Frederick, supra note 23, at 559-60 (same).

112. Nix et al., supra note 105 , at 275.

113. Ryan \& Frederick, supra note 23, at 557-58. In one experiment, Ryan and Frederick found a significant negative correlation between vitality and external motivation, but no significant correlation between vitality and internal motivation. $1 d$. at 553. In another experiment, Ryan and Frederick found a significant positive correlation between vitality and internal motivation, but no significant correlation between vitality and external motivation. Id. at 555 .

Nix et al. found that students who were asked to imagine that they performed successfully in a class that they took out of personal desire checked, on average, "marginally more adjectives indicating vitality," Nix et al., supra note 105 , at 280 , than students who were asked to imagine that they performed successfully in a class that they took because they were required to take the course, although the difference did not rise to the level of statistical significance at the .05 level. Id. at 279-80. Specifically, in this experiment, Nix et al. asked college students to predict how they would feel after receiving an " $\mathrm{A}$ " on a midterm and learning the material in a class, controlling for the circumstances under which the students had decided to take the class. Id. at 279 . One set of students was given the following description of the circumstances of their taking the course:

Imagine that you are enrolled in a class that is not required for your major but which you have always wanted to attend. The subject has always intrigued you, but you have never had a chance to investigate it. Although the course is not required, you find the material challenging and want to do well at it. You realized when you signed up for the course that the material would be entirely new to you, but this was the only chance you would get for the next several semesters to take this course and you really wanted to give it a try now. In short, you are taking this course only because you are interested in learning and you find the material intriguing.

$I d$. Nix et al. characterized this set of circumstances as the "autonomous condition." Id. In this scenario, the student chose to take the course because the student had a personal desire to take the course. Id. Another way to describe this condition would be the internally motivated condition because the student was taking the course because the student personally wanted to take the course. See id. at 269 . The student was not taking the course because of external compulsion or pressure to take the course. See id.

Another set of students was given a different description of the circumstances of their taking the course:

Imagine that you have enrolled in a class that is required for your major but which you don't want to attend. The subject does not interest you and you see no use for the 
"without any emphasis being put on performance pressure or evaluation"114 have shown a greater rise in vitality after performing the task than individuals who perform the same task with the consciousness of being evaluated or judged based on their performance. ${ }^{115}$ Moreover, feelings of competence have also been correlated with vitality. ${ }^{116}$

material being taught. However, because the course is required for your major, you must do well at it. You realized when you signed up for the course that the material would be entirely new to you, but this was the only chance you would get for the next several semesters to take this course and you really need to take it now. In short, you are taking this course only because you have to and you feel a lot of pressure to do well.

Id. at 279. Nix et al. characterized this set of circumstances as the "controlled condition." Id. The student was not taking the course out of a personal desire to take the course but because the student was required to take the course for the student's major. Id. Another way to describe this condition would be the externally motivated condition because the student was taking the course because of an external compulsion to take the course and not because the student personally wanted to take the course. See id. at 269.

The controlled condition in this experiment actually includes two different features that are both relevant to vitality: first, the student is taking the course because the student is required to take the course (although the student has no personal desire to take the course) and second, the student "feel[s] a lot of pressure to do well" in the course. Id. at 279. Although the description of the autonomous condition states that the student "want[s] to do well," the autonomous condition does not emphasize success in the course to the same extent as the controlled condition. Id.

The students' vitality was measured by having the students select adjectives from a list that the students felt "describe[d] their experience following receipt of the ' $\mathrm{A}$ ' on their midterm." Id. Students in the autonomous condition "check[ed] marginally more adjectives indicating vitality than those in the required condition." Id. at 280.

114. Nix et al, supra note 105 , at 277.

115. Id. at 278 . This difference in average reported vitality was statistically significant. Id. In this experiment, Nix et al. gave individuals puzzles to complete. Id. at 276-77. One group of individuals was given the puzzles "without any emphasis being put on performance pressure or evaluation." Id. at 277. The other group of individuals was given the puzzles and told "that these puzzles are increasingly being used as measures of intelligence." Id. As they completed the puzzles, individuals were given feedback that was intended to reinforce the task-orientation or performance-orientation of their assigned group. Id. The individuals' vitality was assessed both before and after they completed the puzzles. Id. at 277-78. The individuals who completed the puzzles under the task-oriented conditions "showed a greater rise in vitality" than the individuals who completed the puzzles under the performance-oriented conditions. Id. at 278. Similarly, Thayer and Moore conducted an experiment in which one group of students was asked to perform a task and given "instructions [that] contained statements of the importance of the experiment, and several admonitions to do as well as possible ... [and was] told that performance on the task correlated with intelligence." Thayer \& Moore, supra note 108 , at 280 . These students reported feeling less energy (specifically, "general activation") than two other groups of students for whom performance was not similarly emphasized, although Thayer and Moore note that the difference was not statistically significant. Id. at 282 . Although there was not a significant difference in the groups' performance on the task, Thayer and Moore note that the students in the performance-emphasizing group tended to perform better. Id. at 282 .

116. Ryan \& Frederick, supra note 23, at 560 (referencing Kennon M. Sheldon, Richard Ryan \& Harry T. Reis, What Makes for a Good Day? Competence and Autonomy in the Day and in the Person, 22 Personality \& Soc. Psychol. Bull. 1270 (1996)); see also id. at 559-60 (reviewing literature regarding vitality and stating "[t]hese findings lend support to our conceptualization of subjective vitality as a feeling of personal energy associated with agency, which can be 
Vitality adds a crucial component to law student enthusiasm: the subjective energy felt by a law student in connection with law study. As this Article explores later, ${ }^{117}$ theory and research regarding vitality-including the relationships between autonomy and vitality, and competence and vitality-inform an understanding of law student enthusiasm and the means by which legal education can cultivate law student enthusiasm.

\section{Interest and Vitality Combined}

The enthusiasm paradigm provides a way to define, ${ }^{118}$ and therefore, more explicitly and deliberately examine law student enthusiasm.119 In defining law student enthusiasm as a combination of interest and vitality associated with the study of law, the enthusiasm paradigm provides a definition of law student enthusiasm that is both grounded in psychology theory and research and also a good intuitive "fit" for the positive, desirable characteristics of a law student. ${ }^{120}$

diminished by factors that block or hinder autonomy or competence"); Nix et al., supra note 105, at 281 ("Regarding competence, we specifically believe that negative feedback or failure experiences will detract from subjective vitality, though the present studies do not address that hypothesis.").

117. See infra notes $118-140,209-317$ and accompanying text.

118. Although many critiques of legal education reference law student enthusiasm, it is not clear whether these critiques are all using "enthusiasm" consistently and what, exactly, it means for a law student to be enthusiastic. See, e.g., Human Nature, supra note 2, at 263; Making Docile Lawyers, supra note 2, at 2034, 2041 n.59.

119. Developing definitions of terms used regarding legal education may be both the result of and the inspiration for research. For example, psychology research informs the definition of "law student enthusiasm" proposed in this Article. At the same time, this definition of "law student enthusiasm" also suggests specific areas for research in legal education (regarding law students' interest for and vitality regarding law study). Cf. Human Nature, supra note 2, at 249 ("A functional definition [of "humanizing"] is overdue and increasingly appropriate, particularly in light of the new empirical evidence regarding the actual effects of legal education."); London et al., supra note 10, at 456 (suggesting that research regarding legal education "be informed by theoretical models and experimental methodologies used in the field of social psychology").

120. Researchers have suggested a possible relationship between vitality and interest. See Nix et al., supra note 105, at 279,282; see also id. at 272-73 (referencing the work of other researchers who have 'identified two different 'process' factors associated with aroused task engagement. One that they called flow mood corresponds well with our vitality construct, consisting of the adjectives energetic, interested, and excited." (citing Carol Sansone, Daniel A. Sachau \& Charlene Weir, Effects of Instruction on Intrinsic Interest: The Importance of Context, 57 J. PERSONAlity \& Soc. Psychol. 819 (1989))).

Nix et al.'s research raises the question of a connection between vitality and interest: specifically, Nix et al.'s experiment regarding students' expectations about their vitality after receiving an "A" on an exam in either the autonomous condition or the controlled condition. See id. at 278-80 (discussed supra note 113). The autonomous condition described the student taking the course because the student was interested in the course material: "you are taking this course only because you are interested in learning and you find the material intriguing." Id. at 279 . The controlled condition described the student taking the course because the student was required to 
Including interest in the definition of law student enthusiasm makes sense because it captures a law student's knowledge about law study and a law student's value for law study.121 As used in the enthusiasm paradigm, interest is a combination of both knowledge about a particular activity and value for that activity. ${ }^{122}$ According to the fourphase model of interest development, interest can deepen or recede, and learners at different phases of interest possess particular characteristics with respect to their activity of interest. ${ }^{123}$ Moreover, students with a well-developed individual interest for law study would identify with their role as law students, be receptive to feedback, and want to further develop their skills. ${ }^{124}$ Students with a well-developed individual interest for law study would also be inquisitive. ${ }^{125}$ They would want to engage in law study and would persevere in law study in the face of difficulty or frustration. ${ }^{126}$

Including vitality in the definition of law student enthusiasm is appropriate because it captures the energy that a law student feels in connection with law study. Vitality refers to a personal, subjective sense of possessing energy. ${ }^{127}$ Vitality has been found to be positively correlated with autonomy. ${ }^{128}$ Especially given the relationship between vitality and autonomy, including vitality as a component of enthusiasm is also consistent with recent research regarding the role of autonomy in legal education and in law students' well-being. ${ }^{129}$

take the course, although the student had no interest in the course material: "The subject does not interest you and you see no use for the material being taught." Id.

In addition, factors that influence vitality, such as autonomy, also play a role in interest. See id. at 281; Developing Interest for Writing, supra note 54, at 14; $c f$. Ryan \& Deci, supra note 23, at 707 ("[A]utonomous acts are characterized by being in accord with one's values or interests.").

121. Interest also captures a student's positive feelings associated with law study. See Putting Things into Words, supra note 29, at 117-18.

122. Individual Interest, supra note 27 , at $375-76$. Interest also includes an individual's positive feelings for an activity. Putting Things into Words, supra note 29, at 117-18.

123. The Four-Phase Model of Interest Development, supra note 22, at 112.

124. See Developing Interest for Writing, supra note 54, at 2-3 (stating that students with a well-developed individual interest for writing identified with their role as writers and were receptive to feedback because it would help them improve their writing); see also The Four-Phase Model of Interest Development, supra note 22, at 115 (stating that an individual with a welldeveloped individual interest has internalized his or her interest).

125. See The Four-Phase Model of Interest Development, supra note 22, at 115 (explaining that an individual with a well-developed individual interest may formulate "curiosity questions" and try to discover the answers to those questions).

126. See id. (explaining that an individual with a well-developed individual interest will pursue the focus of their interest independently and will persevere in the face of difficulty).

127. Ryan \& Frederick, supra note 23 , at 530.

128. Id. at $557-60$.

129. Understanding the Negative Effects, supra note 12. Sheldon and Krieger examined two different aspects of autonomy in legal education. First, Sheldon and Krieger assessed the extent to which students' felt that their professors supported their autonomy ("perceived autonomy 
Defining law student enthusiasm as a combination of both interest for law study and vitality regarding law study, thus, takes into account the subject-specific nature of law student enthusiasm (enthusiasm for law study) as well as the nature of the student's relationship with that subject: the student's knowledge regarding law study, the student's value for law study, and the student's subjective feelings of energy in connection with law study. ${ }^{130}$ This definition of enthusiasm thus

support"). Id. at 888. Second, Sheldon and Krieger assessed the extent to which students' psychological need for autonomy was satisfied. Id. Sheldon and Krieger found that perceived autonomy support predicted the satisfaction of students' psychological needs for autonomy, competence, and relatedness. Id. at 890 . However, Sheldon and Krieger found that perceived autonomy support did not account for the entire relationship between a student's law school and psychological need satisfaction. Id. at 890-91. Sheldon and Krieger also found that autonomy need satisfaction predicted students' self determined career motivation and subjective well-being. Id. at 890. Sheldon and Krieger's research is discussed in more detail later in this Article. See infra notes 168-208 and accompanying text.

130. Another construct that has some relation to interest and vitality is motivation. See Ryan \& Frederick, supra note 23, at $540 \mathrm{n} .3$ ("[M]otivation is typically conceptualized as energy plus direction . . . ."); Deci, supra note 92, at 45 ("[S]everal theories of human motivation have referred to people as being intrinsically motivated when they are freely doing what interests them."). An individual with an individual interest may reflect the same characteristics as an intrinsically motivated individual (an individual who is pursuing a task for its own sake). See Individual Interest, supra note 27 , at 373 ("[T] he behaviors of intrinsically motivated individuals and people engaged with content that is of individual interest are positive, fully engaged, and appear to be focused on a given task for the sake of the task itself."); id. at 390 ("Although students working with individual interest can always be understood to be motivated, all motivated behavior does not necessarily reflect well-developed individual interest."); id. ("People working with contents of well-developed individual interest are motivated learners, in the sense that their activity appears purposeful, sustained, and ever deepening."); $i d$. at 395 (comparing and contrasting individual interest and intrinsic motivation); see also Deci, supra note 92, at 49 ("When a person reports interest, excitement, and enjoyment with respect to an activity, one can be reasonably sure that the person is intrinsically motivated for that activity."); Ivar Bråten \& Bodil S. Olaussen, Profiling Individual Differences in Student Motivation: A Longitudinal Cluster-Analytic Study in Different Academic Contexts, 30 Contemp. Educ. Psych. 359, 369 (2005) (using student interest as one factor to assess student motivation). Some of the means that Renninger and Lipstein identify to support interest development are quite similar to means that have been identified to support intrinsic motivation (an individual engaging in an activity for its own sake): "(a) support of self-determination, through both the provision of greater choice and a focus on personally meaningful material, and (b) promotion of perceived competence, through both positive feedback and optimal levels of challenge." Patrick et al., supra note 20, at 218 (citations omitted).

However, interest as used in this Article to inform an understanding of law student enthusiasm is distinguishable from the construct of motivation. See Individual Interest, supra note 27, at 373 ("Although there is an overlap in the outcomes of intrinsic motivation and well-developed individual interest ... there are also important differences between these concepts."); id. at 373-74 (noting that the literature regarding intrinsic motivation does not necessarily distinguish between different types of interest); id. at 376 (distinguishing individual interest from, inter alia, intrinsic motivation because individual interest "is specific to each individual and it includes two interrelated components: stored knowledge and stored value"); $i d$. at 395 (comparing and contrasting individual interest and intrinsic motivation); see also Deci, supra note 92, at 46 ("[A] person is not necessarily interested in the activities he or she is motivated to do.... [T] he quality of one's motivated behavior differs as a function of the extent to which the person is interested in the 
presents a more complete, accurate picture of law student enthusiasm than descriptions of enthusiasm that concentrate more particularly on outward manifestations of energy ${ }^{131}$ or a general sense of excitement that is not specific to a particular subject area. ${ }^{132}$

\section{The Cultivation of Law Student Enthusiasm as a Priority for Legal EdUCATION}

In addition to providing a working definition of "law student enthusiasm" that is based in psychology theory and research, the enthusiasm paradigm both offers the cultivation of law students' enthusiasm for law study as a priority for legal education, particularly during the first year of law school, and identifies specific ways in which legal education could be modified in order to cultivate law students' enthusiasm for law study. ${ }^{133}$

The enthusiasm paradigm offers another construct for examining and understanding the distress that many law students experience, particularly during the first year of law school. ${ }^{134}$ The first year of law school is an intense experience that can be a difficult transition for law students. ${ }^{135}$ Moreover, law students' difficulties may persist through-

activity."). But see Individual Interest, supra note 27 , at 396 (stating that individual interest "needs to be recognized as a specified type of intrinsic motivation that differs from that on which intrinsic motivation has typically focused").

Moreover, it is an overgeneralization to talk about "the construct of interest" and "the construct of motivation" as if there is only one definition of "interest" and "motivation" because there are many different perspectives and bodies of research regarding each of these terms. See Interest, Learning, and Development, supra note 34, at 3-25 (reviewing interest theories and research); Edward L. Deci \& Richard M. Ryan, Intrinsic Motivation and Self-Determination in Human Behavior 3-40 (1985) [hereinafter Intrinsic Motivation] (reviewing motivation theories and research).

131. See Patrick et al., supra note 20, at 220.

132. Some students may possess a general excitement for learning. See Heads and Hearts, supra note 2 , at 75 (noting that many law students "lose . . their passion for learning"); $i d$. at 89 (noting "that second graders and first-year law students share an excitement for learning"); $i d$. at 111 (noting that one of the author's goals when teaching second graders and law students was "to maintain their eagerness to learn"). However, law students are immersed in learning the law, so a definition of law student enthusiasm should take into account the subject specific nature of the law student experience. See Maranville, supra note 19, at 53 (noting that legal education should instill "passion for the law-passion in the sense of boundless enthusiasm").

133. The enthusiasm paradigm thus adds to existing literature that asserts that "generating passion" for law should be a fundamental goal of legal education. See Maranville, supra note 19, at 73 ; see also id. at 53 . The cited article uses "boundless enthusiasm" as one definition of "passion," but does not further define "enthusiasm." Id. at 51 n.1, 53; see also Michael E. Carney, Narcissistic Concerns in the Educational Experience of Law Students, 18 J. PsyCHIATRY \& L. 9, 27 (1990) (stating that increased interaction between law students and professors would "promote dedication to and enthusiasm for the law," without defining "enthusiasm").

134. See Heads and Hearts, supra note 2, at 75.

135. See Making Docile Lawyers, supra note 2, at 2034. 
out law school. ${ }^{136}$ The enthusiasm paradigm accounts for some of the distress experienced by law students. The curriculum and pedagogy of the first year of law school may presume that students enter law school with a greater degree of enthusiasm for law study than they actually have: with a more developed interest for law study and with more vitality regarding law study than they actually have.

During the first year of law school, students are expected to learn new material, work independently, receive feedback and apply it to future work, and persevere in the face of challenge. The learners who are best able to meet these expectations are students with a well-developed individual interest for law study. ${ }^{137}$ However, these students may not predominate within the first-year law student population. First-year law students might experience some of their distress because they are being taught as if they have a greater level of enthusiasm for law study than they actually have. ${ }^{138}$ There may, therefore, be a disconnect between the way first-year law students are taught and the way first-year law students need to be taught. ${ }^{139}$ Prioritizing the

136. See Does Legal Education, supra note 2, at 274.

137. See The Four-Phase Model of Interest Development, supra note 22, at 115 (describing the characteristics of individuals with a well-developed individual interest).

138. See generally Shanfield \& Benjamin, supra note 5. Although some law students may enter law school with some degree of interest for law study (which may account for the references to first-year law students' "enthusiasm" in the literature), it may not be the well-developed individual interest that could sustain these students through the rigors of the first year of law school (which may account for the references to law students' loss of "enthusiasm" in the literature). See supra note 2 and accompanying text; see also Shanfield \& Benjamin, supra note 5, at 71 ("[The] lack of commitment to law can be a factor in [law student] distress ...."). This point raises the question of whether a student must be in a particular phase of interest for law study in order to be described as possessing enthusiasm for law study. On the one hand, just as students can be in different phases of interest, pursuant to the four-phase model of interest development, so too might students possess different levels of enthusiasm for law study. See, e.g., The FourPhase Model of Interest Development, supra note 22; Putting Things into Words, supra note 29. On the other hand, it is possible that students should only be described as having enthusiasm for law study if they possess a certain level of interest for law study (for example, a well-developed individual interest for law study). Given that interest is one component of enthusiasm, it seems logical to conceive of varying levels of enthusiasm, consistent with the four-phase model of interest development. See The Four-Phase Model of Interest Development, supra note 22. However, all levels of enthusiasm are not sufficient to sustain a student through the first year of law school and, as with interest, a student's level of enthusiasm is dynamic and may deepen or diminish. Id. at 112. Accordingly, one of the goals of legal education should be to cultivate a deep, sustained (and sustaining) enthusiasm for law study. Additional research regarding law students' enthusiasm for law study will contribute to a better understanding-and perhaps a more refined definition-of law student enthusiasm.

139. One reason for this disconnect may be that law professors have more enthusiasm for law study than law students, and consciously or unconsciously orient their teaching to students with enthusiasm for law study. See Individual Interest, supra note 27, at 393 n.13 (noting that teachers with a well-developed individual interest need to be sensitive to ways to teach students who do not share that level of interest and "aware that having a well-developed individual interest in a 


\section{cultivation of law student enthusiasm is one way to remedy this dis-} connect and prevent some of the distress experienced by law students. ${ }^{140}$

subject matter could lead one to make assumptions about the ways in which others learn"); Human Nature, supra note 2, at 283 (noting that law professors may be significantly different from many law students with respect to the skills that they prioritize and their law school experience as law students); Barbara Glesner Fines, Competition and the Curve, 65 UMKC L. Rev. 879,879 (1997) ("In judging pedagogical issues, most law professors favor their own experiences as students . . . ."); cf. Joanne Ingham \& Robin A. Boyle, Generation X in Law School: How These Law Students Are Different From Those Who Teach Them, 56 J. Legal Educ. 281, 289 (2006) (reporting differences between the learning-style preferences of students and professors). See generally Gerard van de Watering \& Janine van der Rijt, Teachers' and Students' Perceptions of Assessments: A Review and a Study into the Ability and Accuracy of Estimating the Difficulty Levels of Assessment ltems, 1 EDuc. Res. Rev. 133 (2006) (reviewing research regarding teach. ers' ability (or lack thereof) to predict accurately the difficulty level of test items and student performance, and describing the authors' research project that found that, inter alia, law teachers tended to overestimate anticipated student performance).

140. Gerry Hess stated that his goal for his first-year law students should be the same as his goal for the second grade students that he used to teach-to have his students end the year with the same excitement (and high expectations) with which they started the year. Heads and Hearts, supra note 2, at 75; see also CARNEGIE RePORT, supra note 1, at 39 (describing the goals of the lawyering program at one law school as "to move students with demonstrated academic talents and interests in the direction of what one professor called 'an enthusiasm for legal practice, a love of lawyering'"); $c f$. id. at 152-53 (describing a required introductory engineering course at the University of Michigan and stating that "the course is intended to help students understand the nature of engineering work and to generate enthusiasm and a sense that they belong in the field"). However, Hess stated that he did not "think about this very often because I have failed so miserably at achieving this goal with law students. The law school experience systematically beats those feelings and expectations out of many of them." Id.

Cultivating enthusiasm for law study might also prevent some of the distress experienced by practicing lawyers to the extent that enthusiasm for law study is an important part of the foundation on which enthusiasm for law practice is based. The Carnegie Report and Best Practices focus on legal education as the preparation for law practice. The very title of the Carnegie Report makes this connection clear: Educating Lawyers: Preparation for the Profession of Law. See Carnegie Report, supra note 1. As part of preparing students for law practice, the Carnegie Report notes the importance of giving students the "motivation to pursue genuine expertise." Id. at 173. An important part of pursuing expertise is learning about the law. If law schools do not cultivate their students' enthusiasm for law study, then this lack of enthusiasm for learning the law may well extend into law practice. Law practice requires on-going law study as lawyers develop and refine their legal knowledge. A law graduate who does not have an enthusiasm for law study may be less "motivat[ed] to pursue genuine expertise" in law practice. Id. This may impede the lawyer's professional development, but it may also be the cause of distress if the lawyer is not actually enthusiastic about the work that law practice requires. Even if a law student wants to become a lawyer, that student may not necessarily be enthusiastic about law study or the other work that law practice requires. See Schwartz, supra note 103, at 391, 423 (distinguishing between students' desire to become lawyers and students' desire to study law). Although this Article focuses on law students' enthusiasm for law study, it would also be worth examining whether lawyers' lack of enthusiasm for law study-and law practice-are sources of lawyer distress. In fact, the Carnegie Report explicitly connects deficiencies in legal education to problems in the legal profession:

Insofar as law schools choose not to place ethical-social values within the inner circle of their highest esteem and most central preoccupation, and insofar as they fail to make systematic efforts to educate toward a central moral tradition of lawyering, legal educa- 


\section{A. Recent Examinations of Legal Education}

The enthusiasm paradigm adds to the existing literature critiquing legal education by focusing attention on the cultivation of students' enthusiasm for law study and by providing a foundation of theory and research on which to examine law student enthusiasm and ways to cultivate law student enthusiasm. Because the enthusiasm paradigm does not exist in a vacuum, but rather is an addition to existing examinations of legal education, this Section discusses two recent studies of legal education: the Carnegie Report, and Kennon Sheldon and Lawrence Krieger's empirical studies regarding law students. ${ }^{141}$ Section B then discusses what the enthusiasm paradigm adds to existing examinations of legal education. ${ }^{142}$

\section{The Carnegie Report}

The Carnegie Report's primary focus is the role of legal education in preparing students to be lawyers. ${ }^{143}$ In fact, the Carnegie Report repeatedly describes the "formative" nature of legal education, ${ }^{144}$ with respect to its role in developing students into "competent and responsible legal professionals." 145 The Carnegie Report identifies three specific purposes of legal education: giving students a foundation of knowledge regarding the law, developing skills that students will need to practice law, and developing in students an awareness and appreciation of their professional responsibilities as lawyers. ${ }^{146}$ The Carnegie Report advocates that law schools purposefully develop a program of

tion may inadvertently contribute to the demoralization of the legal profession and its

loss of a moral compass, as many observers have charged.

Carnegie Report, supra note 1 , at 140 .

141. See infra notes $143-208$ and accompanying text.

142. See infra notes 209-224 and accompanying text.

143. CARnegie RePort, supra note 1 , at $1-2$. On its very first page, the Carnegie Report describes law school as "the crucial portal to the practice of law." $I d$. at 1.

144. See, e.g., id. at 85 (noting "the formative dimension of professional education," "the formative aspect of professional education," and "the formative effects of pedagogical practice"); see also id. at 12 (stating that the Carnegie Report's "emphasis is on fostering in the legal academy more focused attention to the actual and potential effects of the law school experience on the formation of future legal professionals"); $i d$. at 13 (stating that legal education should "focus on the professional formation of law students"); id. (stating that "the formation of competent and committed professionals deserves and needs to be the common unifying purpose" of legal education).

145. Id. at 145; see also id. at 171 (referencing "law schools' capacity to develop competent and responsible lawyers").

146. See, e.g., id. at 194. Specifically, the Carnegie Report describes the first element as "[t]he teaching of legal doctrine and analysis, which provides the basis for professional growth," the second element as "[i]ntroduction to the several facets of practice included under the rubric of lawyering, leading to acting with responsibility for clients," and the third element as "[a] theoretical and practical emphasis on inculcation of the identity, values, and dispositions consonant with 
legal education that integrates the development of law students' knowledge, skills, and professionalism in order to better prepare students for law practice. ${ }^{147}$

The Carnegie Report criticizes the prevailing system of legal education for its overriding focus on legal analysis and legal doctrine-particularly during the first year of law school. ${ }^{148}$ The Carnegie Report also criticizes legal education for being too compartmentalized: courses focus on one aspect of students' preparation to be practicing lawyers (knowledge, skills, or professionalism) and do not reflect how all three aspects are an integral, simultaneous part of lawyering. ${ }^{149}$ As a result, the Carnegie Report advocates for not only a more integrated program of legal education, where knowledge, skills, and professionalism are taught together, but a contextualized program of legal education, where students learn about knowledge, skills, and professionalism in the context of law practice. ${ }^{150}$ Students should understand how what they are learning in law school is significant to law

the fundamental purposes of the legal profession." Id. The Carnegie Report also identifies "six tasks" involved in "prepar[ing] professionals":

1. Developing in students the fundamental knowledge and skill, especially an academic knowledge base and research

2. Providing students with the capacity to engage in complex practice

3. Enabling students to learn to make judgments under conditions of uncertainty

4. Teaching students how to learn from experience

5. Introducing students to the disciplines of creating and participating in a responsible and effective professional community

6. Forming students able and willing to join an enterprise of public service Id. at 22 .

147. See, e.g., id. at 194. The Carnegie Report does not discount the importance of learning legal analysis and doctrine. $I d$. at 13 . However, according to the Carnegie Report, legal analysis and doctrine should not be the exclusive or disproportionate focus of legal education, and legal analysis and doctrine may be best appreciated in the context of law practice. Id. As the Carnegie Report states: "The analysis, critique, and development of legal doctrine thus, in combination, constitute the first, essential element of legal education. However, this type of knowledge often comes most fully alive for students when the power of legal analysis is manifest in the experience of legal practice." Id.; see also id. at 14 ("We believe if legal education had as its focus forming legal professionals who are both competent and responsible to clients and the public, learning legal analysis and practical skills would be more fully significant to both the students and faculty.").

148. See, e.g., id. at 13,83-84. The Carnegie Report focuses largely on the first year of law school "because that experience is so significant in shaping the whole of legal education." $I d$. at 3; see also id. at 17 (noting "the extraordinary power of the first-year experience as a way of beginning the formation of future professionals"). Although the Carnegie Report recognizes that not all law schools have identical curricula and pedagogy, the Carnegie Report notes that "curriculum [and pedagogy] at most schools follows a fairly standard pattern." Id. at 3.

149. Id. at 124 ("The separation of these phases into distinct areas of the curriculum, or as separate apprenticeships, is always an artificial 'decomposition' of practice. The pedagogical cycle is not completed unless these segregated domains are reconnected.").

150. Id. at $124-25$. 
practice, and students should be given the opportunity to apply what they are learning in law school to law practice (simulated or actual). ${ }^{151}$ The Carnegie Report suggests that the integration and contextualization of legal education might help to prevent the disengagement of second- and third-year law students. ${ }^{152}$

\section{Informed by literature regarding learning theory, with a particular} focus on how novices in a particular field become experts, ${ }^{153}$ the Car-

151. Id. at 58-59 (noting "the forced decontextualization that students experience in the standard first-year curriculum"); id. at 60 ("How their ability to think like a lawyer will be used in practice remains, for most students, only a vaguely imagined future.").

152. See id. at 88. The authors of the Carnegie Report recommend "designing [the third year of law school] as a kind of 'capstone' opportunity for students to develop specialized knowledge, engage in advanced clinical training, and work with faculty and peers in serious, comprehensive reflection on their educational experience and their strategies for career and future professional growth." William M. Sullivan, Anne Colby, Judith Welch Wegner, Lloyd Bond \& Lee S. Shulman, Summary: Educating Lawyers: Preparation for the Profession of Law 9 (2007), available at http://www.carnegiefoundation.org/dynamic/publications/elibrary_pdf_632. pdf; see also CARNEGIE REPORT, supra note 1, at 195; id. at 77 (noting the need to rethink the second and, particularly, the third year of law school).

Although the Carnegie Report critiques legal education and suggests reforms for legal education, noting that legal education is largely consistent from one law school to the next, the Carnegie Report also recognizes that all law schools are not identical and that some law schools do offer courses or approach curriculum design in ways that reflect the recommendations of the Carnegie Report. See, è.g, id. at 120 ("[S]ome schools have modified the standard first-year curriculum to make clinical courses more prominently available as first-year electives."); id. at 151 ("Some ... schools provide special experiences in the first year that introduce students to the broader context and significance of the law. These first-year programs serve as a counterbalance to the intensive focus on legal analysis that is the heart of the first-year experience."); see also BEST PRACTICES, supra note 2, at 275 ("[T]here are components of many law schools' existing programs of instruction that are consistent with our recommendations."). In examining legal education for the Carnegie Report, sixteen law schools in the United States and Canada were observed during the 1999-2000 academic year. CARNEGIE REPORT, supra note 1, at 15 . At that time, there were aspects of law schools that reflected the Carnegie Report's recommendations, and since that time, law schools have continued to make changes to their curricula and pedagogy. See, e.g., Best PRACTICES, supra note 2, at 286 (describing recent curricular changes at Harvard Law School); Stanford Law School Grade Reform FAQ, http:/www.law.stanford. edu/news/statement (last visited Apr. 28, 2009) (describing changes to grading system); Washington and Lee School of Law Announces Dramatic Third Year Reform, http://law.wlu.edu/news/ storydetailpr.asp?id=376 (last visited Apr. 28, 2009) (describing new, experiential third-year curriculum).

153. CARnegie RePort, supra note 1, at 116-17; see also id. at 22 ("[P]rofessional education aims to initiate novice practitioners to think, to perform, and to conduct themselves (that is, to act morally and ethically) like professionals."); $i d$. at 26 ("Learning, then, entails embarking on an effort to gradually grow into the complex abilities of an expert.").

The Carnegie Report conceives of legal education that is designed to help students transition from novices to experts as an "apprenticeship." Id. at 22. Specifically, there are apprenticeships that correspond to each of the three purposes or components of legal education: "the cognitive, practical, and ethical-social apprenticeships." Id. at 183. The ethical-social apprenticeship, or the "apprenticeship of professional identity" encompasses "both the area of professional ethics ... and the wider matters of morality and character." Id. at 129 . The Carnegie Report is particularly concerned with the lack of attention to the ethical-social apprenticeship in legal education 
negie Report critiques legal education both for its heavy reliance on summative assessment ${ }^{154}$ as the means to provide feedback to students and for its relative lack of formative assessment. ${ }^{155}$ The Carnegie Report advocates for more formative assessment in law school in order to help guide students to become more capable practicing lawyers. ${ }^{156}$

In addition, the Carnegie Report critiques the prevailing manner in which summative assessment is carried out in legal education: a single, end-of-term exam that is graded on a curve. ${ }^{157}$ The Carnegie Report notes that this form of grading can demoralize law students both because a student's grade is determined by only one event, ${ }^{158}$ and because that grade depends, in part, on how all of the students in the course performed on the exam. ${ }^{159}$

While the Carnegie Report repeatedly describes legal education as formative, forming law students into legal professionals-in some ways suggesting that students are the passive objects of legal educa-

given law schools' role in forming students' professional identities as lawyers. Id. at 127. Moreover, the Carnegie Report notes that this dimension of legal education warrants careful attention because of "the growing sense of demoralization in legal practice." Id.

154. Summative assessment is assessment for the purposes of grading or ranking. Id. at 164. Giving a student a grade on an exam is a form of summative assessment. Id.

155. Id . at 167 . Formative assessment is assessment for the purpose of providing guidance or feedback with the goal of helping the student to develop and improve. Id. at 171 .

156. Id. at 171; see also id. at 189 ("Formative practices directed toward improved learning ought to be primary forms of assessment.").

157. Id. at $164-70$.

158. Id. at 166-67; see also id. at 165 ("Students' comments about assessment in their first year of law school often expressed puzzlement, frustration, and anguish. ... Many felt that the testing was unfair, counterproductive, demoralizing, and arbitrary."); Rolando J. Díaz, Carol R. Glass, Diane B. Arnkoff \& Marian Tanofsky-Kraff, Cognition, Anxiety, and Prediction of Performance in 1st-Year Law Students, 93 J. Educ. Psychol. 420, 421 (2001) ("Final examinations in law school are highly stressful in that they typically determine the entire grade for a course ...." (citing Philip C. Kissam, Essay, Law School Examinations, 42 VAND. L. REv. 433 (1989))).

159. Carnegie Report, supra note 1 , at 168-69. The Carnegie Report offers criterion-referenced assessment as an alternative to curved (or normative) grading. Id. at 170 . Criterion-referenced assessment means that each student would be graded according to his or her performance relative to a particular standard of performance (according to which all students in a class would be assessed). $I d$. at 168,170 . A student would be graded based upon the extent to which his or her performance satisfied the standard and not based upon the extent to which his or her performance satisfied the standard relative to how well his or her classmates' satisfied the standard. Id. at 170. According to criterion-referenced assessment, all students in a class could do well or poorly because their grade would not be determined by their relative performance. Id. Although criterion-referenced assessment is not without its difficulties, it would remedy some of the problems with curved grading. Id.; see also, e.g., id. at 149 (noting that curved grading can generate competitiveness among students and lead to the demoralization of students); $i d$. at 163 (stating that because curved grading means "by deliberate plan, all cannot excel, the school faces an endemic problem of retaining student interest and effort after the first cut, which is decisive, is made at the end of the first year"). 
tion-the Carnegie Report notes that the goal of legal education is to create students who are self-regulated and engaged with respect to their learning as law students and their lives as practicing lawyers. As the Carnegie Report states:

Ultimately, the goal of formative education must be more than socialization seen as molding human clay from without. Rather, formative education must enable students to become self-reflective about and self-directing in their own development. Seen from a formative perspective, law school ought to provide the richest context possible for students to explore and make their own the profession's possibilities for a useful and fulfilling life. The school contributes to this process by opening apprenticeship to its students as effectively as its faculty is able. Concretely, this means enabling students to grasp what the law is, as well as how to think within it, just as it means giving students experience of practicing the varied roles lawyers play while coming to appreciate the engagements of self and the world that these entail. 160

The Carnegie Report is not the only critique of legal education; rather, the Carnegie Report is a recent, comprehensive critique of legal education that reflects critiques that have consistently been made about legal education. ${ }^{161}$ For decades, legal education has been examined and criticized, ${ }^{162}$ and recommendations have been made for

160. Id. at 85-86; see also id. at 173 ("[T]he essential goal of professional schools must be to form practitioners who are aware of what it takes to become competent in their chosen domain and to equip them with the reflective capacity and motivation to pursue genuine expertise. They must become 'metacognitive' about their own learning, to use the psychologists' term.").

161. The Carnegie Report itself draws on other critiques of legal education. See, e.g., id. at 197 (referencing the work of the Institute for Law Teaching at Gonzaga University School of Law and Best Practices). Best Practices is another recent, comprehensive critique of legal education that offers specific proposals for legal education reform. Best Practices, supra note 2. The vision of legal education articulated in the Carnegie Report and Best Practices are very similar, and Best Practices includes many of the same critiques and suggestions for legal education reform that are made in the Carnegie Report. See, e.g., id. at 8-9 ("Law schools should organize their curriculums to develop knowledge, skills, and values progressively; integrate the teaching of theory, doctrine, and practice; and teach professionalism pervasively throughout all three years of law school."). Best Practices, in fact, frequently references and quotes extensively from the Carnegie Report. See, e.g., id. at 19. Best Practices also draws on the research of Kennon Sheldon and Larry Krieger, discussed infra at notes 168-208 and accompanying text. See, e.g., Best Practices, supra note 2, at 1, 33, 113-14. Best Practices contains many references to past critiques of legal education and proposals for the reform of legal education, as well as references to literature regarding learning and pedagogy generally. See, e.g., id. at 3, 17, 106, $146,239-40$.

162. See Carnegie Report, supra note 1, at 91-96 (reviewing some past critiques of and efforts to reform legal education); $i d$. at 189 ("Law schools have been sent stern messages about these issues for decades."); see also BEst PRACTICEs, supra note 2, at 285 ("A growing body of scholarship acknowledges the shortcomings of legal education and proposes new approaches for educating law students."); Heads and Hearts, supra note 2, at 79 ("Any number of reforms to legal education have been proposed ...."). Following up on the Carnegie Report, ten schools have formed the Legal Education Analysis and Reform Network (LEARN). LEARN: LEGAL 
its reform with respect to the very same features of legal education that the Carnegie Report highlights: the artificial separation between doctrine, skills, and professionalism; ${ }^{163}$ the disproportionate emphasis on doctrine and legal analysis; 164 the failure to consider learning theory in law school pedagogy; ${ }^{165}$ the lack of formative assessment; ${ }^{166}$ and the downsides of the means by which summative assessment is carried out (a single, end-of-term exam; curved grading). ${ }^{167}$

Education Analysis and Reform Network, General Description of Planned Projects 2009-2010 (2009), http://www.law.stanford.edu/display/images/dynamic/events_media/ LEARN_030509_Ir.pdf [hereinafter LEARN PLANNED PROJECTS]. LEARN has identified a number of projects that it will undertake to promote awareness about existing innovations in legal education and encourage continued reflection about and innovations to improve legal education. Id.

163. See, e.g., Best Practices, supra note 2, at viii, 97-100.

164. See, e.g., Carnegie Report, supra note 1, at 57, 95, 100 (noting that Best Practices critiques the heavy reliance on the Socratic method in law school pedagogy and advocates contextualized legal education); Heads and Hearts, supra note 2, at 106-08 (advocating for the use of formative assessment in law school and giving examples of ways to provide formative assessment in law school classes).

165. See generally Best PRActices, supra note 2.

166. See, e.g., id. at 255-59. One critique is that the lack of formative assessment (and minimal summative assessment) undermines learning because it puts too much pressure on students to perform well during those instances when their performance can be judged (for example, when a student is called on in class). See id. at 220-21 (quoting Peggy Cooper Davis \& Elizabeth Ehrenfest Steinglass, A Dialogue About Socratic Teaching, 23 N.Y.U. Rev. L. \& Soc. Change 249 (1997)); see also id. at 260 (stating that determining a student's grade in a course based upon that student's performance on a single exam is less likely to accurately measure that student's ability because "a single assessment produces higher levels of stress because of its significance to the student's grade in the course and future"); Díaz et al., supra note 158, at 427 (suggesting that "students could be better prepared for the novel experience of taking law school exams if they were given practice on this type of task before the end of the semester"); Making Docile Lawyers, supra note 2, at 2036 ("The significance of grades thus becomes inflated because without more personalized feedback, grades provide students with the only indication of their performance.").

167. See, e.g., Best Practices, supra note 2, at 236 ("The single exam tradition remains with us today, despite long-standing criticisms from academics, practitioners, and students."); id. at $237,243-45$ (criticizing curved grading and advocating for the use of criterion-referenced assessment); id. at 259-60 (recommending that students' grade in a course be determined by more than one summative assessment); Human Nature, supra note 2, at 297-300 (criticizing curved grading); see also CARNEGIE REPORT, supra note 1, at 167 (noting that law school assessment has been criticized "[a]s far back as 1924" and reviewing past critiques of law school assessment); Heads and Hearts, supra note 2, at 78 (noting that concern with grades and class rank causes significant stress for law students and that "[t]he significance of grades becomes inflated because students get so little feedback during the semester that grades are the only indicator of their performance"); Glesner Fines, supra note 139 (critiquing law school grading practices); Díaz et al., supra note 158, at 427 (suggesting that "students could be better prepared for the novel experience of taking law school exams if they were given practice on this type of task before the end of the semester"); Making Docile Lawyers, supra note 2, at 2043 (recommending the use of multiple methods of summative assessment). 


\section{Sheldon and Krieger's Empirical Research}

While the Carnegie Report focuses on the role of legal education in preparing students for law practice, Sheldon and Krieger's work examines law students' experience in law school: specifically, changes that law students experience during law school and particular features of the law school experience that may be related to such changes. ${ }^{168}$

Sheldon and Krieger's work is informed by self-determination theory, ${ }^{169}$ which identifies differing motivations for people's behavior and relates those motivations to psychological and physical well-being. ${ }^{170}$ According to self-determination theory, individuals' psychological needs are most satisfied when individuals engage in activities for the sake of those activities themselves or when individuals engage in activities for reasons that the individuals believe are important. ${ }^{171}$ According to self-determination theory, individuals have a need for autonomy: a need to feel that they are in control of their actions and that they act in a particular way because they choose to act in that way, rather than acting because they are compelled to do so (for example, to comply with the demands of other people). ${ }^{172}$ According to

168. Does Legal Education, supra note 2, at 262; Understanding the Negative Effects, supra note 12 .

169. Does Legal Education, supra note 2, at 263. Self-determination theory also informs the work of researchers who study vitality. See, e.g., Ryan \& Deci, supra note 23, at 702.

170. According to self-determination theory, motivation can be "intrinsic" or "extrinsic." Does Legal Education, supra note 2, at 264 . Intrinsic motivation means that an individual is engaging in an activity for the sake of that activity itself (for the personal pleasure or meaning derived from engaging in that activity). Extrinsic motivation means that an individual is engaging in an activity "as a means to an end, rather than as an end in itself." Id. at 263. Selfdetermination theory identifies three different types of extrinsic motivation: "identified," "introjected," and "external." Id. Identified motivation means that an individual is engaging in an activity for reasons that the individual believes to be important. Id. (describing extrinsic motivation as internalized if "the person identifies with the rationale and value behind the behavior"). Introjected motivation means that an individual is engaging in an activity to avoid negative internal consequences: because the individual would feel "ashamed, guilty, or anxious" if the individual did not engage in the activity. Id. at 263-64. External motivation means that an individual is engaging in an activity because the individual feels compelled by someone else to engage in the activity. Id. at 263.

According to self-determination theory, activity that is the result of intrinsic or identified motivation is "autonomous" because the individual is undertaking the behavior because the individual finds the behavior enjoyable or personally meaningful. Id. at 268 . Behavior that is the result of external or introjected motivation is "non-autonomous, or controlled" because the individual is undertaking the behavior out of a sense of obligation or requirement. Id.

171. Id. at 263.

172. According to self-determination theory, external motivation is not autonomous because it is the product of "external pressures" (compelled by the demands of other people). Id. Introjected motivation is not autonomous because the individual is acting in order to avoid negative feelings (out of a sense of "internal compulsion[ ]") rather than because the individual feels positively about his or her actions. Id. 
self-determination theory, self-determined behavior is associated with greater physical and psychological well-being, while behavior which is not self-determined is associated with diminished physical and psychological well-being. ${ }^{173}$

In addition to differentiating between intrinsic and extrinsic motivation, self-determination theory also differentiates between internal and external values. ${ }^{174}$ According to self-determination theory, "values" refers to "what people seek through their actions." 175 Self-determination theory classifies values such as "intimacy, community, and personal growth" as internal (or intrinsic) values and values such as "money, image, and fame" as external (or extrinsic) values.176 According to self-determination theory, individuals who disproportionately value external values also possess "diminished [subjective wellbeing]."177

Sheldon and Krieger's research with law students examines the application of self-determination theory to the law school environment. ${ }^{178}$ Sheldon and Krieger's first study measured the subjective well-being of students at four different times during their law school experience: on their first day of law school, in March of their first

173. Self-determined motivation can be both the cause and outcome of psychological wellbeing. Understanding the Negative Effects, supra note 12 , at 884 . On the one hand, self-determined behavior can result in psychological needs being met. $I d$. On the other hand, self-determined behavior can be considered an outcome of an individual's psychological needs being met. $I d$. Sheldon and Krieger's research examines self-determined motivation as the outcome of psychological need satisfaction, rather than as the cause of psychological need satisfaction. Id. at 885.

174. Does Legal Education, supra note 2, at 264.

175. Id.

176. $I d$.

177. Id. ("[D]ata indicate that there is no negative effect from strongly valuing money, popularity and appearance per se, provided that the person does not ascribe them more importance than ... intrinsic values ....").

178. Sheldon and Krieger have explained that:

[Self-determination theory] provide[s] one potential way of understanding why students' [subjective well-being] might decline over time. If students begin law school with intrinsic motivations and internalized extrinsic motivations (striving for reasons of interest and/or personal conviction) but then move towards non-internalized or 'controlled' motivations (striving for reasons of external coercion, fear, or guilt), this could produce a loss of satisfaction and engagement, and ultimately contribute to the many observed problems in the legal profession. Also, if students begin with intrinsic value contents (such as helping others or personal growth) but move towards extrinsic values (such as impressing others, or gaining status and affluence), this would also help explain the negative trends in [subjective well-being], as well as perhaps explaining the negative stereotypes (i.e. shallowness, greed, hyper-competitiveness) commonly associated with lawyers.

Id. at 264. See generally Human Nature, supra note 2 (using self-determination theory as the foundation for a critique of and recommendations to reform legal education). 
year of law school, in November of their second year of law school, and in November of their third year of law school. ${ }^{179}$ In order to measure the students' subjective well-being, Sheldon and Krieger had the students take surveys that measured the students' "positive affect, negative affect, and life satisfaction."180 Sheldon and Krieger found that, although incoming law students report greater levels of well-being than upper-level undergraduate students, ${ }^{181}$ these same law students reported "large reductions in positive affect, life satisfaction, and overall [subjective well-being], and large increases in negative affect, depression, and physical symptoms" towards the end of their first year of law school.182 Sheldon and Krieger also found that the students' decline in subjective well-being persisted over the second and third years of law school as well; ${ }^{183}$ students did not " "rebound" " after the first year of law school to the levels of subjective well-being that they reported at the very beginning of their law school experience. ${ }^{184}$

In addition to assessing students' positive affect, negative affect, and life satisfaction, Sheldon and Krieger asked students about their goals for law school and their reasons for having those goals. ${ }^{85}$ Sheldon and Krieger found that the students "experienced reduced overall self-determination from the beginning to the end of their first year."186 Specifically, students' intrinsic motivation declined while

179. Does Legal Education, supra note 2, at 267.

180. Id. "Positive and negative affect refer to happy and unhappy mood states, respectively, whereas life satisfaction refers to global cognitive judgments about one's life as a whole." Id. at 267-68.

Sheldon and Krieger also had students fill out questionnaires to measure students' physical health and depression. Id. at 268.

181. Sheldon and Krieger administered a survey to undergraduate students in August 2001, and this group served as a comparison group for the law students. Id. at $267,270-71$.

182. Id. at 272.

183. In addition to assessing students' positive affect, negative affect, and life satisfaction, Sheldon and Krieger "created an aggregate [subjective well-being] score for each participant at each time, by adding positive affect and life satisfaction, and subtracting negative affect." $I d$. at 268.

184. Id. at 274.

185. Sheldon and Krieger gave students four options to choose from in identifying their reasons for their goals, reflecting different levels of personal autonomy and intrinsic motivation (or lack thereof) as defined by self-determination theory. The four reasons from which students were to choose were "because of the enjoyment and stimulation that this activity provides you," " "because you really believe it is an important goal to have,", "'because others want you to or think you should," and "because you would feel ashamed, guilty, or anxious if you didn't." "Id. at 268. The first two of the four reasons "are conceptualized as autonomous by [self-determination theory]." Id. The last two of the four reasons "are conceptualized as nonautonomous, or controlled, by [self-determination theory]." Id. As with subjective well-being, Sheldon and Krieger created an aggregate self-determination score for each student by subtracting the sum of the controlled scores from the sum of the autonomous scores. Id. at 269.

186. Id at 273. 
students' extrinsic motivation increased over the first year of law school. ${ }^{187}$

Sheldon and Krieger also measured students' values at all four times that the students were surveyed. In order to measure students' values, Sheldon and Krieger used a survey instrument that asked students to rate the importance of various circumstances happening in their future. ${ }^{188}$ Sheldon and Krieger found that students "became significantly less endorsing of intrinsic values relative to extrinsic values overall, during the course of the first year."189 Moreover, the strength of students' values (both extrinsic and intrinsic) in all but one category ${ }^{190}$ declined significantly from March of the students' first year to November of the students' second year, "suggest[ing] that rather than moving further towards extrinsic and away from intrinsic values, as they did from time 1 to time 2 , students instead reported less valuing of all kinds at time 3."191

In examining the relationship between changes in subjective wellbeing, self-determined motivation, and values over the first year of law school, Sheldon and Krieger found that "declines in self-determination ... were significantly associated with increases in negative af-

187. Id.

188. For example, "I will have many expensive possessions" " and "I will help others improve their lives." II. at 269.

189. Id. at 273. The extrinsic values were "financial success, appealing appearance, and social popularity." Id. at 269 . The intrinsic values were "emotional intimacy, community contribution, and personal growth." Id. Sheldon and Krieger created "an aggregate "[i]ntrinsic value orientation' measure, derived by summing the three intrinsic scores and subtracting the three extrinsic scores." Id.

The law students started out with "more intrinsic values overall" than the comparison sample of undergraduate students. Id. at 270. As with subjective well-being, Sheldon and Krieger found that students' decline in intrinsic valuation did not "'rebound." Id. at 274.

Although students' intrinsic values decreased relative to their extrinsic values, Sheldon and Krieger did not find that students' career choices reflected this change. Id. at 273, 275. Sheldon and Krieger hypothesized that students would become more interested in "money-oriented careers" than in "service-oriented careers" during the first year of law school. Id. at 275 . However, Sheldon and Krieger did not find that this was the case. Id. In fact, Sheldon and Krieger reported that "students as a whole moved away from the careers we felt most clearly reflected a 'money' orientation." Id. On the other hand, consistent with their hypothesis, Sheldon and Krieger did find that "[grade point average] correlated positively with change towards moneyoriented careers . . . and negatively with change towards service-oriented careers." Id.

190. The exception was the "appearance" category. Id. at 274.

191. Id. The general decrease in valuing between March of the students' first year and November of the students' second year persisted in the students' third year as well. Id. In other words, the students' values did not significantly change between their second year and third year. Id. Sheldon and Krieger noted that the persistent decrease in valuing from the first year to the second year (that remained constant from the second year to the third year) "appears consistent with previous reports of law-student disengagement from their studies in the second and third years of school, and of a general 'numbing' of values and emotions by excessively analytical legal processes." $I d$. at 282 (citations omitted). 
fect and physical symptoms, and with decreases in positive affect and aggregate [subjective well-being]. Declines in intrinsic value orientation ... were significantly associated with decreases in positive affect, life satisfaction, and aggregate [subjective well-being]."192

Not all scholars agree with Sheldon and Krieger regarding the persistent deleterious condition of law students. ${ }^{193}$ Nonetheless, even these scholars recognize some negative aspects of the law school experience: specifically, the difficulties that the first year of law school can present for law students and the disengagement of students after their first year of law school. ${ }^{194}$

192. Id. at 273. In a follow-up study, Sheldon and Krieger measured the subjective well-being, self-determination, and values of students at a second law school from the beginning of their first year of law school towards the end of their first year of law school. Id. at 276. Sheldon and Krieger noted some differences between the first law school and the second law school, including that the second law school "require[d] first year students to attend several offerings in its Perspectives on the Legal Profession program, which includes topics of well-being, depression, substance abuse, and professional values." Id. In addition, the second law school did not have a curve for grades while the first law school "ha[d] a mandatory curve that include[d] required Ds in all first year sections." Id. at 276-77. In a subsequent article discussing research at these same two schools, Sheldon and Krieger indicated that the second law school had a "suggested," but not mandatory, curve. Understanding the Negative Effects, supra note 12, at 891.

The results of Sheldon and Krieger's research at the first law school were replicated at the second law school: "the students evidenced strong declines in positive affect, life satisfaction, and aggregate [subjective well-being], as well as strong increases in negative affect." Does Legal Education, supra note 2, at 278. Students' "self-determined motivation for attending law school" also declined. Id. (Sheldon and Krieger assessed students' motivation differently at the two different schools. Id. at 277.) Sheldon and Krieger also found that the second law school's students' "reductions in self-determination were correlated with reductions in [subjective wellbeing]." Id. at 279 . In addition, "reductions in intrinsic value orientation" were correlated with reduced subjective well-being. Id.

193. See Gulati et al., supra note 2; James J. White, Maiming the Cubs, 32 Oнго N.U. L. Rev. 287 (2006). But see Joshua D. Rosenberg, A Reply to Professor White, 32 Oнı N.U. L. Rev. 311 (2006).

194. Although they found that first-years and third-years reported similar levels of stress, Gulati et al. found that "reported feelings of depression decline sharply between the first and third year of law school." Gulati et al., supra note 2, at 252. Gulati et al. note the intensity and novelty of the first year of law school, describing it as "a uniquely challenging experience." $I d$. at 251; see also id. at 252 ("[F]or those [first-year students] who feel they are not adapting to the new environment and not fitting in, the process can produce feelings of both stress and depression."); $i d$. at 257 (describing the first year of law school as "relentless").

Gulati et al. compared the results of a survey that was administered to first-year law students in 1995 (at the end of the first semester) with the results of a survey that was administered to third-year law students in 1997 (at the end of the second semester). Id. at 241-42. Unlike Sheldon and Krieger's research, Gulati et al. did not compare survey results for the same students during both their first year and third year of law school.

Based on the results of the comparison between the first-year surveys and the third-year surveys, Gulati et al. concluded that third-year law students were disengaged from, but satisfied with, law school. Id. at 247-48; see also INDIANA UNIVERSITY CENTER FOR POSTSECONDARY Research, Law School Survey of Student Engagement: Law School Report 2007, OVERVIEw 7 (2007) [hereinafter LSSSE OvERVIEw] ("Students were generally satisfied with their law school experience. Eighty-two percent of all students rated their law school experience 


\section{Sheldon and Krieger's more recent work has focused on the role of "perceived autonomy support"195 on law students. ${ }^{196}$ Looking at the}

'good' or 'excellent.' Only $3 \%$ said their experience was 'poor.'"). Gulati et al. found that although third-year law students were more critical of their law school than first-year law students, third-year law students were still generally positive about their law schools. Gulati et al., supra note 2, at 249. Gulati et al. concluded that "[t]he emotional well-being, satisfaction, and optimism of third-year law students are all relatively high." Id. at 254 . However, Gulati et al. did discover that there was a minority of third-year students who registered "high levels of stress and, in particular, feelings of depression far more commonly than other law students." Id. at 256.

Gulati et al. reconciled their findings that third-year law students were disengaged but satisfied by concluding that law students perceive law school's utility to be in the credentials that it provides, rather than expecting law school to prepare the law students for law practice. In fact, third-year law students were much more likely to agree with the statement, "'Law school teaching is too theoretical and unconcerned with real-life law practice," "than first-year law students. Id. at 246 (noting that forty-three percent of third-year students agreed with this statement, while eighteen percent of first-year students agreed with this statement). Gulati et al. concluded that law students disengage from law school after the first year because "[o]nce they are done competing for admission to school, first-year grades, and law review membership, they have no particular reason to be involved with the law school scene." Id. at 256; see also CARnegie RePORT, supra note 1, at 139 (noting "the slackening of interest among students in the third year"). On the other hand, first-year students are more engaged and anxious because of the significance of first-year grades and law review membership to the hiring process. Gulati et al., supra note 2, at 258. Gulati et al. suggest that the third year of law school could be reformed to be more relevant to students' lives as practicing lawyers after law school and, therefore, promote students' engagement. Id. at 262-66.

Another author, while recognizing that first-year law students may experience increases in depression and that law students may be depressed and anxious, attributes such conditions not to problems with legal education but to the adjustment to law school and, perhaps, "the challenge of hard learning and of confronting the looming need to prepare to behave as a lawyer." White, supra note 193, at 288. But see Does Legal Education, supra note 2, at 262 (noting that prior studies have indicated that "law students soon evidence poorer mental health than medical students, another difficult professional program"). White reviews Sheldon and Krieger's research reported in their 2004 article and other researchers' work and concludes that, although first-year law students experience a decline in subjective well-being and an increase in depression, "the data do not live up to the claims about serious injury and do not support the exhortation for radical revision of law school teaching." White, supra note 193, at 296; see also Bråten \& Olaussen, supra note 130, at 391 . As Bråten and Olaussen note:

[Professional students' declining motivation might be] an undesirable but inevitable effect of profession-oriented education. Many individuals may start their studies with a somewhat groundless enthusiasm or optimism because they do not fully understand what is required of them in higher education. Over time, they may naturally cool down as they adjust their motivational beliefs to the realities of the classroom, in particular to the feedback and social comparison information provided to them.

Id.

195. When an individual feels autonomous, the individual feels that he or she is in control of his or her own actions-acting as a result of his or her own decisions, rather than based upon direction from others. Understanding the Negative Effects, supra note 12, at 885 . According to self-determination theory, there are three characteristics of an environment that is supportive of individual autonomy:

(a) choice provision, in which the authority provides subordinates with as much choice as possible within the constraints of the task and situation; (b) meaningful rationale provision, in which the authority explains the situation in cases where no choice can be 
combined data from both law schools, Sheldon and Krieger found that subjective well-being declined significantly from the beginning of the first year of law school to the third year of law school. ${ }^{197}$ In addition, need satisfaction with respect to the needs of autonomy and relatedness declined significantly as well. ${ }^{198}$ Looking at the data from each law school separately, Sheldon and Krieger found the same pattern (significant declines in subjective well-being, and autonomy and relatedness need satisfaction). ${ }^{199}$

When comparing the law school samples, Sheldon and Krieger found that the law schools differed regarding their students' perceived autonomy support. ${ }^{200}$ The second law school was perceived to be

provided; and (c) perspective taking, in which the authority shows that he or she is aware of, and cares about, the point of view of the subordinate.

Id. at 884. Autonomy supportive environments promote intrinsic or internalized motivation, while autonomy undermining environments impede intrinsic or internalized motivation. Id.

196. Id. at 888 . (In addition to learning more about law students, one of Sheldon and Krieger's main goals for this research project was to test a specific theoretical model for self-determination theory. $I d$. at 886 .) The students at one of the law schools were surveyed at the beginning of their first year of law school (during orientation), towards the end of their first year of law school, and then during the fall of their third year of law school. Id. at 887 . The students at the second law school were surveyed at the beginning of their first year of law school (during the first week of classes), towards the end of their first year of law school, and then in the spring of their third year of law school. Id.

Sheldon and Krieger used the same two law schools for the studies that were reported in both their 2004 and 2007 articles. Id. At one law school (the second law school), the same students were the subjects of the studies reported in both articles. Id. At the other law school (the first law school), different students were the subjects of each study. Id. As Sheldon and Krieger also noted in their 2004 article, these law schools "appear[ed] to have somewhat different educational and pedagogical philosophies." Id. at 886; accord Does Legal Education, supra note 2, at 276-77. Among some of the differences, according to Sheldon and Krieger, the second law school focused more on law practice experience and teaching ability in faculty hiring, while the first law school focused more on scholarship (regarding not only hiring but also salary increase decisions). Understanding the Negative Effects, supra note 12, at $886,895 \mathrm{n} .2$. The second law school also offered more skills training courses for its students and "regularly provide[d] teaching skills seminars for its faculty." Id. at 886 .

197. Id. at 889 .

198. Id. According to self-determination theory, there are three primary psychological needs: "autonomy, competence, and relatedness." Id. at 885; see also Kennon M. Sheldon, Andrew J. Elliot, Youngmee Kim \& Tim Kasser, What Is Satisfying About Satisfying Events? Testing 10 Candidate Psychological Needs, 80 J. Personality \& Soc. Psychol. 325, 337 (2001) (identifying "autonomy, competence, relatedness, and self-esteem" as psychological needs). "Autonomy" means that individuals "are doing what they choose and want to be doing, that is, what they enjoy or at least believe in." Understanding the Negative Effects, supra note 12, at 885 . "Competence" means that individuals "need to feel that they are good at what they do or at least can become good at it." Id. "Relatedness" means that individuals "are relating meaningfully to others." Id. Sheldon and Krieger assessed students' autonomy, competence, and relatedness need satisfaction. Id.

199. Understanding the Negative Effects, supra note 12, at 889.

200. Sheldon and Krieger assessed the extent to which students felt that their professors supported their autonomy. Id. at 888 . 
more autonomy supportive than the first law school.201 Sheldon and Krieger found that "perceived autonomy support predicted greater autonomy, competence, and relatedness need satisfaction."202 In addition, perceived autonomy support predicted "greater self-determined career motivation [and] higher [grade point average] . . . and greater [subjective well-being]."203 Sheldon and Krieger also found that competence, autonomy, and relatedness need satisfaction all predicted subjective well-being. ${ }^{204}$

In light of these results, Sheldon and Krieger recommended that law schools "focus on enhancing their students' feelings of autonomy." 205 Sheldon and Krieger also suggested that law schools become more responsive to "the priorities of their students and provide choices consistent with those priorities."206 Sheldon and Krieger suggested that there may be a disconnect in legal education between students' goals or priorities in law school and law schools' goals or

201. Id. at 890,893 . In addition to finding that law school was a significant predictor of perceived autonomy support, Sheldon and Krieger also found that sex and age were significant predictors of perceived autonomy support. Id. at 890. Specifically, "women and older participants perceived law school to be less autonomy supportive." Id.

202. Id. at 893 .

203. Id. at 890 .

204. Id. at 893 .

205. Id. at 894; see also Best Practices, supra note 2, at 113-14 (recommending that law schools "support student autonomy" and discussing Sheldon and Krieger's research in support of this recommendation); $c f$. Dawson R. Hancock, Effects of Test Anxiety and Evaluative Threat on Students' Achievement and Motivation, 94 J. Educ. Res. 284, 288 (2001) ("[C]lassroom situations in which students perceive the need to compete with one another and in which professors exert significant influence over classroom procedures and student behavior negatively influence student performance on examinations."). Sheldon and Krieger recommend that law schools focus on autonomy support, although psychological need satisfaction mediated the relationship between perceived autonomy support and the "final outcomes." Understanding the Negative Effects, supra note 12, at 893-95. Perceived autonomy support would seem to be a salient factor, and autonomy is one of the psychological needs, also suggesting the salience of autonomy support. Another possibility, though, would be to focus more broadly on means by which students' psychological needs are satisfied. Sheldon and Krieger's research, in accordance with self-determination theory, focused on perceived autonomy support as the means by which psychological needs are satisfied, but there are likely other means for satisfying psychological needs that should be explored. In addition, perceived autonomy support did not solely account for all of the factors in the model (for example, law school had significant direct effects on both competence satisfaction and subjective well-being). Id . at 892 (suggesting the utility of looking at factors in addition to perceived autonomy support). See id. at 894 (suggesting future research into the impact of particular academic experiences on students).

206. Understanding the Negative Effects, supra note 12, at 894. 
priorities. 207 Finally, Sheldon and Krieger noted the need for further research regarding, inter alia, students' experiences in law school. ${ }^{208}$

\section{B. The Enthusiasm Paradigm's Contribution to Existing Examinations of Legal Education}

The enthusiasm paradigm identifies a pressing priority for legal education: the cultivation of law student enthusiasm for law study. The Carnegie Report notes certain aspects of the law school experience that can be "demoralizing" for students. ${ }^{209}$ Sheldon and Krieger's research reviews prior literature regarding law student "distress," 210 and adds additional evidence to this body of work. ${ }^{211}$ The enthusiasm paradigm offers an additional explanation for some of the distress felt by law students: law students' lack of enthusiasm for law study. Moreover, the working definition of "law student enthusiasm" that the enthusiasm paradigm provides enables scholars to discuss and study law student enthusiasm in a way that is deliberate, clear, consistent, and grounded in a body of theory and research regarding interest and vitality. Examining legal education through the lens of the enthusiasm paradigm provides a basis to more meaningfully examine legal education and identify areas for its reform.

The enthusiasm paradigm complements the Carnegie Report because while the Carnegie Report focuses on the role of law schools in preparing students to be practicing lawyers, ${ }^{212}$ the enthusiasm paradigm focuses on the salience of the law school experience for law students while they are in law school. The enthusiasm paradigm highlights the value of improving students' experience in law school for its own sake. At the same time, the enthusiasm paradigm offers a means by which the goals of the Carnegie Report can be accomplished: by cultivating students' enthusiasm for law study, law schools will be better able to develop law students who have the "complete involvement with learning" 213 that the Carnegie Report asserts is essential "to become expert in a profession."214 The Carnegie Report

207. Id. ("We would expect, for example, that students are generally seeking quality teaching and that they attend law school to learn to practice law. However, law schools traditionally emphasize theoretical scholarship and the teaching of legal theory, and many hire and reward faculty primarily based on scholarly potential and production.").

208. Id. at 894-95.

209. CARnegie Report, supra note 1 , at 149.

210. Does Legal Education, supra note 2, at 262.

211. Id. at 272.

212. See supra notes $143-167$ and accompanying text.

213. CaRnegie Report, supra note 1 , at 27.

214. Id.; see also id. at 160-61 ("[O]ne essential goal of professional schools must be to form practitioners who are aware of what it takes to become competent in their chosen domain and to 
identifies "six tasks" involved in "prepar[ing] professionals."215 The enthusiasm paradigm identifies a seventh task: the cultivation of law students' enthusiasm for law study.

Moreover, because the enthusiasm paradigm is based on an existing body of psychology theory and research, the enthusiasm paradigm offers a way to study law student enthusiasm. The enthusiasm paradigm identifies specific components that can be examined to assess the existence and depth of students' enthusiasm for law study: students' interest for law study and students' vitality associated with law study. 216 Some law students might come to law school with some degree of interest for law study and vitality associated with law study; however, it is not clear at all how many students fall into this category. Many law students may enter law school with little or no real enthusiasm regarding law study. ${ }^{217}$ The enthusiasm paradigm provides a basis for assess-

equip them with the reflective capacity and motivation to pursue genuine expertise."); Glesner Fines, supra note 139, at 907 ("At a time when even 'successful' lawyers are increasingly dissatisfied with the practice of law, law schools may want to consider their contribution to this decline."). Moreover, the enthusiasm for law study that students develop in law school may carry over into students' lives as practicing lawyers. See Carnegie RePort, supra note 1, at 146 ("The kind of personal maturity that graduates need in order to practice law with integrity and a sense of purpose requires not only skills but qualities such as compassion, respectfulness, and commitment.").

215. Carnegie Report, supra note 1 , at 22.

216. The enthusiasm paradigm raises the question of how to assess students' enthusiasm for law study. Although there are existing instruments for surveying law students about aspects of their law school experience, these survey instruments are not designed to measure law students' enthusiasm (interest and vitality) for law study. The most prominent, widely-used law student survey instrument is the Law School Survey of Student Engagement. See, e.g., LSSSE OverVIEw, supra note 194. However, the LSSSE is administered to first-, second-, and third-year law students in the spring, and so does not capture the state of mind of incoming law students or students during their first semester of law school. Id. at 1. Kennon Sheldon and Lawrence Krieger have also developed a law student survey instrument, Dynamic Assessment of Law School Outcomes (DALSO), which is based on their research with law students. Human Nature, supra note 2 , at 264 n.57.

Researchers have noted the value of studying students as they enter a new educational environment. London et al., supra note 10, at 467 . The author of this Article has designed two surveys: one to be administered at the beginning of students' first year of law school and one to be administered towards the end of students' first year of law school. These surveys are intended to assess, inter alia, students' interest and vitality for law school. The author has administered versions of these surveys to two law school first-year classes and will be administering revised versions of the surveys to future law school classes.

This author is extremely appreciative of Ann Renninger's contributions to this research project, which include: speaking with the author about both of their research interests, sharing copies of some of her publications with the author, giving the author advice about the author's research project, and sharing a survey that she administered to students about their interest for writing. Two of the questions in this author's surveys were modified from questions that Ann Renninger used.

217. The author's on-going research projects are intended to provide information regarding, inter alia, incoming law students' enthusiasm for law study. See supra note 216. Other authors 
ing entering law students' enthusiasm for law study and students' enthusiasm for law study as they progress through law school.

In finding that law students' intrinsic motivation decreased over the course of their first year of law school, ${ }^{218}$ Sheldon and Krieger's research may suggest that law students' enthusiasm for law study diminishes over the course of the first year of law school. In studies at two different law schools, Sheldon and Krieger found that first-year law students' intrinsic motivation decreased. ${ }^{219}$ Because intrinsic motivation reflects that an individual is engaged in an activity for the sake of the activity itself_- "being motivated by enjoyment and interest" 220 these findings suggest that students' enthusiasm for law study might, in fact, diminish over the first year of law school. However, although Sheldon and Krieger asked students to identify their reasons for their law school goals or for attending law school according to the types of motivation identified by self-determination theory, ${ }^{221}$ Sheldon and Krieger did not directly assess the extent of students' interest for law study or vitality associated with law study. ${ }^{222}$

have observed that law students do not necessarily come to law school with knowledge about either legal education or law practice. See Peter Kutulakis, Stress and Competence: From Law Student to Professional, 21 CAP. U. L. REv. 835, 836 (1992) ("Many students are not prepared for what they encounter when they come to law school. They know very little about the whole process of legal education, and even less about the profession itself."); see also Glesner, supra note 9, at 646, 653 (noting that law students do not necessarily know "what to expect from law school" or law practice).

218. Does Legal Education, supra note 2, at 273, 281.

219. Id. at 281. Sheldon and Krieger also found that students experience a decline in subjective well-being over the course of the first year of law school (which persists after the first year of law school) and a decline in their "self-determined motivation for [attending] law school." Id. at 280.

Although students at both schools evidenced a decrease in their intrinsic motivation during their first year of law school, the students at the two different law schools did evidence some differences regarding the specific types of motivation that varied during their first year of law school. The students at the first school evidenced a decrease in their intrinsic motivation and an increase in their external motivation during their first year of law school. Id. at 273 . There were "no significant changes" in these students' introjected or identified motivation during their first year of law school. Id. The students at the second school evidenced a decrease in their intrinsic motivation and an increase in their introjected motivation during their first year of law school. Id. at 278-79. These students' identified motivation increased "somewhat." Id. at 279. (Sheldon and Krieger used a different methodology to assess the students' motivation at the second law school than they used to assess the students' motivation at the first law school. Id. at 277.)

220. Id. at 279. While Sheldon and Krieger refer to intrinsic motivation as motivation that is a result of an individual's "interest" in an activity, they do not define "interest." See, e.g., id. at 264. Interest theory and research help explain what it means for an individual to possess interest. The definition of interest as comprised of both knowledge and value, along with positive feelings, is a particularly apt definition for law student interest in law study. See The Four-Phase Model of Interest Development, supra note 22, at 114.

221. Does Legal Education, supra note 2, at 268, 277.

222. See id. at 267-70; Understanding the Negative Effects, supra note 12, at 887-88. 
In addition, the enthusiasm paradigm offers another construct besides Sheldon and Krieger's "perceived autonomy support" for examining legal education. While perceived autonomy support may be an important factor in understanding students' law school experience (and while perceived autonomy support may influence vitality), it is not the only salient factor. In fact, Sheldon and Krieger found that perceived autonomy support did not account for the entire relationship between a student's law school and psychological need satisfaction. ${ }^{223}$ The extent to which a law school cultivates student enthusiasm should also be examined, in addition to the extent to which a law school supports student autonomy.

The enthusiasm paradigm provides a definition of law student enthusiasm, identifies the cultivation of law student enthusiasm for law study as a goal of legal education, and provides a means for studying law student enthusiasm. The enthusiasm paradigm, thus, adds to the existing literature examining legal education and provides a basis for further research regarding legal education. The enthusiasm paradigm also provides a lens through which to examine particular aspects of legal education with an eye towards curriculum design and pedagogy that cultivates student enthusiasm. Part V of this Article examines some specific aspects of legal education through the lens of the enthusiasm paradigm and proposes numerous changes to legal education in order to cultivate law student enthusiasm, while also accomplishing the other important goals of legal education..$^{224}$

\section{Evaluating Legal Education through the Lens of THE ENTHUSIASM PARAdigm}

If the cultivation of enthusiasm for law study is to become one of the priorities of legal education-in particular, during the first year of law school-then the question becomes how to cultivate law students' enthusiasm for law study. Many different aspects of legal education warrant examination through the lens of the enthusiasm paradigm, as informed by existing research regarding interest and vitality. 225 The enthusiasm paradigm has questions about the way in which first-year law students are graded (summative assessment). For example, do a single end of semester exam and curved grading-the grading

223. Understanding the Negative Effects, supra note 12, at 890.

224. See infra notes $225-311$ and accompanying text.

225. The existing theory and research regarding the four phases of interest development and vitality provide a means by which to examine legal education through the lens of the enthusiasm paradigm. Future research specifically regarding law students' interest and vitality for law study will further clarify this view. 
schemes that predominate in the first year of law school-cultivate or impede law student enthusiasm? The enthusiasm paradigm raises questions about the type of feedback (formative assessment) that should be provided to first-year law students. For example, does feedback cultivate or impede law student enthusiasm, and are there different types of feedback that should be provided to students with different levels of enthusiasm for law study? The enthusiasm paradigm raises questions about the first-year pedagogy and curriculum. For example, are there modifications that should be made to the means by which first-year students are taught or the courses that students take in their first year in order to cultivate students' enthusiasm for law study? In fact, the enthusiasm paradigm has implications for virtually every aspect of legal education.226 This Part examines a few specific aspects of assessment (summative and formative), pedagogy, and curriculum for which the enthusiasm paradigm is particularly salient. ${ }^{227}$

\section{A. Assessment}

The first aspect of the law school experience that warrants reexamination in light of the enthusiasm paradigm is assessment, both summative and formative. Critiques of legal education have noted the downsides of the single, end-of-course exam as the prevailing method of summative assessment (grading) in law school.228 Recent critiques of legal education have also stressed the importance of formative assessment (feedback), commenting upon the relative lack of formative assessment in law school and advocating for more formative assess-

226. The enthusiasm paradigm raises questions not only regarding what happens once a student starts law school but also regarding the admission of students to law school. One question is whether a student's enthusiasm for law study (or potential to develop enthusiasm for law study) should be a consideration in the decision to admit that student to law school. If so, law schools are then faced with the question of how to assess students' enthusiasm for law school. Researchers have been trying to develop a new way to "evaluate a broader range of factors related to effectiveness as a lawyer" than assessed by the current Law School Admissions Test (LSAT). Best Practices, supra note 2, at 51 (discussing the work of Marjorie M. Shultz and Sheldon Zedeck (funded by the Law School Admission Council)); see also MARJORIE M. Shultz \& Sheldon Zedeck, Final Report: Identification, Development, and ValidaTION OF PREDICTORS FOR SUCCESSFul LAWYERING (2008), http://ssrn.com/abstract=1353554. These researchers "identified twenty-six factors related to effectiveness as a lawyer." BEST Practices, supra note 2, at 51. One of these factors is "[p]assion and engagement." Id. Although this new test might serve as a better indicator of prospective law students' enthusiasm, it is likely that any law school admissions test would need further revision to assess students' enthusiasm for law study.

227. See infra notes $228-311$ and accompanying text.

228. E.g., Best Practices, supra note 2, at 259-60; Douglas A. Henderson, Uncivil Procedure: Ranking Law Students Among Their Peers, 27 U. Mich. J.L. Reform 399, 411-13 (1994). 
ment in law school. ${ }^{229}$ However, assessment that inhibits the development of enthusiasm for law study or causes developing enthusiasm for law study to regress may undermine the value of assessment. ${ }^{230}$ The research on interest and vitality that underlies the enthusiasm paradigm raises questions about both the appropriate quantity and quality of summative and formative assessment for cultivating law student enthusiasm.

\section{Summative Assessment}

The enthusiasm paradigm raises specific questions regarding summative assessment and the cultivation of law student enthusiasm. First, the enthusiasm paradigm raises questions about the impact of curved, or normative, grading on students' enthusiasm for law study. Second, the enthusiasm paradigm raises questions about the extent to which students should be summatively assessed during law school.

Curved grading has been criticized for demoralizing students and fostering competition among students. ${ }^{231}$ Curved grading may also impede enthusiasm for law study because it diminishes autonomy, ${ }^{232}$ which is related to vitality. 233 Curved grading may diminish autonomy because, in a curved grading system, a student's grade is not solely a function of that student's assessed performance. Rather, in a curved grading system, a student's grade depends in part upon the performance of that student's classmates. Therefore, a curved grading system may diminish autonomy because it removes a measure of control from a student regarding the grade that student receives in a course. ${ }^{234}$

229. See, e.g., BEST PRACTICEs, supra note 2, at 255-59; see also Heads and Hearts, supra note 2 , at 106.

230. It would be particularly troubling if formative assessment impeded the development of enthusiasm for law study because formative assessment has the deliberate, constructive purpose of facilitating learning. See Heads and Hearts, supra note 2, at 106 (discussing the value of formative assessment).

231. See, e.g., CARnegie RePort, supra note 1, at 149, 164-66; Human Nature, supra note 2, at $297-300$ (criticizing curved grading).

232. Human Nature, supra note 2, at 298 (discussing how curved grading undermines autonomy).

233. See Nix et al., supra note 105, at 281-82; Ryan \& Frederick, supra note 23, at 559-60. Moreover, Sheldon and Krieger have highlighted "perceived autonomy support" as a key (although not exclusive) factor that influences students' "psychological need satisfaction." Understanding the Negative Effects, supra note 12, at 890 .

234. See Human Nature, supra note 2, at 298 (discussing how curved grading undermines autonomy). Curved grading may also diminish feelings of competence, which have been correlated with vitality. See Ryan \& Frederick, supra note 23, at 559-60 (reviewing the literature regarding the relationship between vitality and competence, and vitality and autonomy). Curved grading may diminish feelings of competence because a student is evaluated relative to the performance of his or her classmates, not solely relative to a particular standard of performance (as is the case with criterion-referenced assessment). See Human Nature, supra note 2, at 299 (stating that a 
The enthusiasm paradigm also raises questions about the extent to which students should be summatively assessed in law school. In the face of recent critiques of the infrequency of summative assessment in law school, ${ }^{235}$ the enthusiasm paradigm raises the question of whether more frequent summative assessment would impede student enthusiasm for law study and, thus, whether more frequent summative assessment should be avoided, particularly during the first year of law school when the cultivation of enthusiasm is an especially high priority. 236 More frequent summative assessment could impede enthusiasm by fostering a more negative, performance-focused learning environment for law students. ${ }^{237}$ Lipstein and Renninger found that students who do not have a well-developed interest for writing are particularly sensitive to critical feedback. ${ }^{238}$ Before law students develop a well-developed interest for law study, they too might be particularly sensitive to critical feedback: with respect to summative assessment, this feedback could take the form of low or disappointing grades. In addition, individuals who focus on performing a task for its own sake report greater increases in vitality, on average, than individuals who undertake a task that they have been told is indicative of

mandatory curve in combination "with a required grade range that students perceive to be unrealistically low" will result in "lost autonomy and competence"). Therefore, in a very strong class, a student who has performed well, but not as well as his or her classmates, may receive a lower grade than he or she would have received if criterion-referenced grading had been used. It has been noted that "[a]t the heart of an effective teaching and learning environment is the principle that all students can attain a high level of achievement." Heads and Hearts, supra note 2 , at 91 . However, in a curved grading system, this is not actually the case, to the extent that "achievement" is indicated by a high grade. Even if all students in a class perform well, students' grades will be determined by how the students performed relative to their other high-achieving classmates.

On the other hand, curved grading might increase feelings of competence by causing a student to receive a better grade than he or she might have received if criterion-referenced grading were used, if that student performs well compared to his or her classmates. Perhaps, then, a more salient weakness of curved grading is that it may give students an inaccurate impression of their competence (either overstating or understating a student's competence depending on how that student's classmates performed).

235. See, e.g., Best Practices, supra note 2, at 259-60; Carnegie Report, supra note 1, at 164-65. The fact that a student's grade in a law school class is frequently based on a single exam has been criticized as placing a tremendous amount of pressure on a student for that single exam and as being a less-than-valid measure of a student's performance because the student's performance is only assessed on a single occasion. Best Practices, supra note 2, at 260.

236. Although Best Practices advocates for more frequent summative assessment throughout law school, Best Practices recognizes that summative assessment should be timed appropriately in light of the particular skill to be tested and that, especially during the first year of law school, some-but not necessarily all-summative assessment might be better left for the end of semester or year. Best Practices, supra note 2, at 260.

237. See Nix et al., supra note 105, at 276-78.

238. Putting Things into Words, supra note 29, at 123-24. 
intelligence. ${ }^{239}$ Causing students to focus on the evaluation of their performance through summative assessment could interfere with feelings of vitality that are a component of law student enthusiasm. ${ }^{240}$

The enthusiasm paradigm suggests that particular grading practices are worth considering, especially during the first semester of law school. One possibility would be to not assign grades during the first semester of law school, but rather to grade students on a pass/fail basis during the first semester of law school. ${ }^{241}$ Students could be given

239. See Nix et al., supra note 105 , at $276-78$.

240. Moreover, to the extent that every summative assessment event causes stress for law students, multiple summative assessments might increase student distress, thereby diminishing positive feelings associated with law study and impeding the development of enthusiasm. $C f$. The Four-Phase Model of Interest Development, supra note 22, at 114 (identifying "positive feelings" as one component of interest). Although a single exam at the end of a semester might cause significant stress for a law student, that law student, at least, only has to endure one such event in a given course. On the other hand, it is possible that the stress experienced in connection with any particular summative assessment event could diminish if a student had multiple summative assessment events in connection with the same course (for example, because each summative assessment event would be one of multiple summative assessment events influencing a student's grade in a course or because a student might "acclimate" to summative assessment events if the student did not have only one summative assessment event in a course). In addition, student stress might be impacted not only by the number of summative assessment events in a course, but also by the amount of material covered in any one assessment event. See David S. Dustin, Some Effects of Exam Frequency, 21 PsychOL. REc. 409, 410-11, 413 (1971) (over a one-month period, psychology students who were tested weekly on portions of course material reported less test anxiety than students who were tested once on the course material combined).

If anything, it is generally suggested that more frequent summative assessment would be advantageous for students but disadvantageous for their professors (because of the increased time that would be spent on designing and grading assessments). E.g., LEARN PLANNEd Projects, supra note 162, at 24; see also Negin, supra note 2, at 675-76 (reporting that students in two sections of torts who took multiple exams during the course (either three exams plus the final exam or a mid-term exam plus the final exam) received higher mean scores on the final exam than students in a third section who took only the final exam); Carrie B. Myers \& Scott M. Myers, Assessing Assessment: The Effects of Two Exam Formats on Course Achievement and Evaluation, 31 Innovative Higher Educ. 227, 228-30, 231-32, 233-34 (2007) (reporting the findings of the authors' study that students who were tested more frequently in an introductory statistics course received higher scores than students who were tested less frequently; the authors also reported that the section where students were tested more frequently had no attrition and that students in this section "rated both the course and instructor higher compared with students in the [section where students were tested less frequently]," which experienced $11 \%$ attrition after the first exam). But see Glesner Fines, supra note 139, at 911 (noting that while a system of multiple summative assessments in a single course "might indeed reduce student anxiety over individual exams," it would still cause students to focus too much on grades). However, more research needs to be done on the impact of more frequent summative assessment on law students: not only regarding performance but also regarding enthusiasm. This author is currently engaged in an empirical research project that is, inter alia, investigating students' preferences for single versus multiple summative assessments.

241. See Best Practices, supra note 2, at 278; Making Docile Lawyers, supra note 2, at 2043 (recommending the use of pass/fail grading during the first semester of law school); Glesner Fines, supra note 139, at 910 (noting that law schools could "delay ranking [students] until the second semester [of the first year], or even the second year of law school, could base first-year 
feedback on their performance on typical summative assessment measures (for example, exams), but not actually receive a grade beyond pass/fail. ${ }^{242}$ This assessment scheme would give students time to develop enthusiasm for law study: time to focus on studying law and develop an identity as a law student without worrying about their graded performance. ${ }^{243}$ Alternatively, if students were going to be graded during the first semester of the first year, a criterion-referenced grading scheme ${ }^{244}$ could be considered or their grades could be subject to a more generous curve. ${ }^{245}$ As students' enthusiasm for law

grades on a pass/fail system, or could weight the cumulative GPA to give greater emphasis to upper-level grades").

Stanford Law School recently adopted a proposal to revise its grading system. Stanford Law School Grade Reform FAQ, supra note 152. Under the new system, students will receive one of only four possible "grades" in each of their classes: "honors, pass, restricted credit, no credit." Id. Harvard Law School is also similarly revising its grading system. Vesna Jaksic, Law Schools Revamp Their Grading Policies, NAT'L L.J., Feb. 26, 2009, http://www.law.com/jsp/article.jsp?id= 1202428588174.

242. Alternatively, students could receive an unofficial grade for their own knowledge but receive an official pass/fail grade on their transcript. To the extent that grades give students an additional indication of their level of mastery (beyond ungraded feedback alone), giving students unofficial grades would have some benefit. In addition, giving students unofficial grades might help identify students who need academic support (although professors could identify these students based upon their ungraded performance alone) and give students the impetus to take advantage of academic support.

243. While not grading students for their first semester of law school might promote students' enthusiasm for law study, it would mean that employers would not have first-year grades for students when students were seeking summer jobs for the summer after their first year of law school. To the extent that employers rely on grades when making hiring decisions, this could make first-year law students who would have received high grades less marketable. See Glesner Fines, supra note 139 , at $879,886-87$ (noting the utility of grades in the hiring process). On the other hand, it would promote the marketability of capable students who, nonetheless, did not receive high grades in their first semester law school courses. One way to reconcile these concerns could be to have professors identify a designated number of top students in their classes but not grade or otherwise rank students in their first semester of law school. See Human Nature, supra note 2, at $300 \mathrm{n} .197$ (discussing the potential difficulty of eliminating rankings of law students from the employers' perspective and suggesting one way to address that difficulty-by giving employers a student's grade point average and the grade point average for that student's class or the law school as a whole).

244. Criterion-referenced grading means that students are graded according to the extent to which they satisfy particular standards of performance (not according to their performance relative to the other members of their class). CARnEGIE Report, supra note 1, at 170-71. One of the downsides of criterion-referenced grading is that it could result in less standardization of grades because each class would not be subject to a prescribed curve. This might be of particular concern when two professors teach different sections of the same course. See Glesner Fines, supra note 139, at 892 ("Institutional grading policies often are justified as necessary to even out differences among faculty in grading practices."). Also, professors who are accustomed to normative (curved) grading might face some initial difficulty determining their students' grades according to a criterion-referenced system. On the other hand, criterion-referenced grading would enable professors to assign grades that better reflect their students' performance.

245. To the extent that a law school also prescribes a particular grade mean for each course, that mean could be higher for first-year courses. 
study developed, students could be subject to a more rigorous assessment scheme that would reflect students' developing skills and transition to professional standards of practice. ${ }^{246}$

\section{Formative Assessment}

The enthusiasm paradigm also raises questions about both the quality and quantity of formative assessment (feedback) that should be given to law students-particularly first-year law students. As with students at different phases of interest for writing, ${ }^{247}$ students at different phases of interest for law study may be receptive to different types of feedback. Although the goal of formative assessment is to provide constructive feedback to students, ${ }^{248}$ the same feedback might not be constructive for all students. In fact, if professors are not sensitive to their students' phase of interest for law study, professors might actually undermine their students' enthusiasm for law study in their efforts to give their students feedback. Feedback that professors intend to be constructive may not actually be effective because it is geared towards students who have more enthusiasm for law study than students actually possess. However, as discussed in this Subsection, ${ }^{249}$ the goal of providing students with meaningful feedback can be reconciled with the goal of cultivating students' enthusiasm for law study.

Research with students regarding their interest for writing shows that students want "to be heard," 250 but that students have very different preferences for feedback depending upon their phase of interest for writing. ${ }^{251}$ Students with a triggered situational interest for writing do not want to have to make a lot of revisions to their writing and want feedback that seems "manageable."252 These students are very concerned with their audience's perceptions of their abilities and do not want their audience to think that they are not capable. ${ }^{253}$ Students with a maintained situational interest for writing rely on their

246. Assessing upper-level students according to more stringent standards may actually serve to promote enthusiasm for law study. Students with a well-developed individual interest for law study may require additional challenge for their "interest to continue and deepen." See Putting Things into Words, supra note 29, at 137 (stating that for a student with a well-developed individual interest in writing, "[c]ontinued challenges in writing are essential for [that student's] interest to continue and deepen").

247. Id. at 123.

248. Best Practices, supra note 2, at 255.

249. See infra notes $250-277$ and accompanying text.

250. Putting Things into Words, supra note 29, at 123.

251. Id. at 123.

252. Id.

253. Id. 
teacher's "standards of performance" 254 and want specific instructions from their teacher about what they should do to improve their writing. ${ }^{255}$ At the same time, these students want to receive positive feedback about their writing. ${ }^{256}$ Students with an emerging individual interest for writing want to receive positive feedback about their writing and are resistant to critical feedback. ${ }^{257}$ It is only students with a well-developed individual interest for writing who are receptive to the type of "honest," 258 constructive feedback that law teachers are most apt to provide. ${ }^{259}$ Moreover, even students with a well-developed individual interest for writing, who are receptive to feedback, have a preference for the order in which they receive feedback: wanting to receive feedback regarding the content of their writing before feedback about execution. ${ }^{260}$

The fact that students at different phases of interest for writing are receptive to different types of feedback suggests that students at different phases of interest for law study are also receptive to different types of feedback. Although critiques of legal education advocate for more formative assessment, ${ }^{261}$ a focus on formative assessment should also take into account that different quantities and types of feedback might be appropriate for different students depending on their phase of interest for law study. ${ }^{262}$ Feedback might not promote students' enthusiasm for law study and might, in fact, cause students' enthusiasm for law study to wane. For example, for students with a triggered situational interest in law study, a large quantity of feedback or feed-

254. Id.

255. Id.

256. Id.

257. See id. (students with an emerging individual interest for writing "do not want to hear specific directives or questioning of their decision making").

258. Id.

259. Id.

260. Id.

261. See, e.g., CARnegie Report, supra note 1, at 171-72; Best Practices, supra note 2, at 255-59; Heads and Hearts, supra note 2, at 106; see also Ingham \& Boyle, supra note 139, at 291 (suggesting that professors write "copious . . comments," on a graded writing assignment).

262. In discussing "Best Practices for Experiential Courses," Best Practices notes that the value of feedback depends on both the feedback itself and the recipient of the feedback:

The way a person approaches feedback has a substantial impact on the quality of the learning experience for the student. The success of the feedback process depends on both the quality of the feedback and the receptiveness of the student. To be useful to the student, feedback should be relevant and focused on learning dilemmas. Feedback must also be acceptable to the student, who may become defensive and reject criticism. By providing feedback in a way that is constructive, but also readily acceptable to the student, the person providing feedback helps facilitate growth rather than frustration, self-criticism, or complete disconnect on the part of the student.

Best Practices, supra note 2, at 175. 
back that is too abstract might be overwhelming. ${ }^{263}$ These students might not find a large quantity of feedback or abstract feedback to be constructive. Moreover, this type of feedback might not generate the type of positive feelings that are a component of interest ${ }^{264}$ and may impede the development of enthusiasm or cause enthusiasm to diminish. At this early stage of interest for law study, it might be more important to build students' confidence in their capabilities rather than to give students detailed critical (albeit constructive) feedback. ${ }^{265}$

While law professors might be reluctant to give students a false sense of their abilities for the sake of cultivating students' enthusiasm, giving feedback to cultivate enthusiasm can be reconciled with giving legitimate feedback. For example, law professors can be careful to have realistic expectations of students in light of the students' stage in law school. ${ }^{266}$ Law professors' expectations for a student in his or her

263. See Putting Things into Words, supra note 29 , at 123.

264. The Four-Phase Model of Interest Development, supra note 22, at 114

265. It might be particularly important to give students positive feedback during the beginning of their legal education because this is the time when students might be most anxious about their work. See Young, supra note 76, at 418 ("[S]tudents found the earliest assignments to be the greatest source of anxiety."); see also Ann Poulos \& Mary Jane Mahony, Effectiveness of Feedback: The Students' Perspective, 33 Assessment \& Evaluation Higher Educ. 143 (2008) (noting both "the demoralizing impact of negative feedback" and "the importance of feedback to first-year [university] students"). Poulos and Mahony note that feedback for new university students is important not only because of the substantive information that it provides to students regarding their work, but also because feedback can "provide[ ] emotional support and facilitate[ ] integration into university." Poulos \& Mahony, supra, at 152; see also Melanie R. Weaver, Do Students Value Feedback? Student Perceptions of Tutors' Written Responses, 31 Assessment \& Evaluation Higher Educ. 379, 390 (2006) (reporting students' view that "positive feedback [was] very important and . . . increased their confidence").

266. See Watering \& van der Rijt, supra note 139, at 145 (noting that one reason why law teachers overestimated anticipated student performance might have been because the teachers' "expectations were ... too high and, as a consequence, it was difficult to envision the skills and competences of the students").

The question arises of how to assess students' phase of interest for law study in order to tailor feedback to that phase of interest. At the most individualized level, law students' phase of interest for law study could be assessed when they enter law school and then at different points during law school. Law professors could then learn the results of these assessments for their students and take these results into account when giving feedback to their students. See Bråten \& Olaussen, supra note 130, at 392 ("Presumably, different groups of students may benefit from different motivational interventions aimed at maintaining or developing enthusiasm for and appreciation of study work."); see also Young, supra note 76, at 417 (recommending that professors learn how each of their students responds to feedback). However, this system could be quite burdensome for law school administration and, particularly, faculty. Also, for assignments for which feedback is given anonymously, this system would not be easy to implement. It may be more feasible for professors to consider what feedback would be most appropriate in light of what is likely to develop enthusiasm (interest and vitality) for the greatest number of students. Students' stage in law school could be one way to predict students' level of enthusiasm for law study. To assist in this determination, law schools should periodically assess their students' level of enthusiasm for law study and report the results, in general, to the faculty. See supra note 216 
first few weeks of law school and resultant feedback should be quite different from law professors' expectations for a student at the end of his or her first year of law school and resultant feedback. Adjusting expectations and feedback consciously and deliberately based upon students' phase of interest for law study is one way to give meaningful feedback that can also cultivate, rather than impede or diminish, enthusiasm. In addition, because students with a triggered situational interest are particularly concerned with their teachers' impressions of them as being capable, ${ }^{267}$ law professors should make a deliberate effort to both give their students positive feedback and let their students know that they are confident in their students' capacity to further develop their knowledge and skills.

It is particularly important for law professors to make a concerted effort to give positive feedback to first-year law students because students at the earlier stages of interest (triggered situational interest, maintained situational interest, and emerging individual interest) want positive feedback. ${ }^{268}$ Moreover, law professors might well underestimate the importance of positive feedback as students progress through law school. Law professors might believe that as students progress through law school they should be held to higher standards and given more specific, extensive feedback to further develop their knowledge and skills. This may be right, to the extent that students develop a well-developed individual interest for law study as they progress through law school. However, students may be in particular need of positive feedback just when their professors think such feedback is no longer necessary or important. According to Lipstein and Renninger, students with an emerging individual interest in writing identify with their role as writers and are resistant to critical feedback of their writing. ${ }^{269}$ Law students who are developing an individual interest in law study may be similarly resistant to critical feedback, and,

(describing this author's empirical research project regarding, inter alia, first-year law students' interest for and vitality regarding law study).

267. Putting Things into Words, supra note 29, at 123.

268. Developing Interest for Writing, supra note 54, at 2-3. The desire for positive feedback is not limited to younger students; moreover, students may feel the need for more positive feedback than their professors provide. See Weaver, supra note 265 , at 390 . As Weaver stated in describing the results of her research:

Although a large majority of students felt positive feedback to be very important and confirmed it increased their confidence, the evidence showed a decided lack of positive comments. They also clearly identified their need for more of a balance between positive and negative comments, in order to ensure that feedback would motivate rather than discourage.

Id.

269. Putting Things into Words, supra note 29 , at $123,131$. 
at this stage, it may be particularly important to give these students positive feedback in order to encourage their identification with their role as law students.

The only students who may welcome constructive criticism as feedback are those students with a well-developed individual interest for law study. ${ }^{270}$ However, the vast majority of first-year law students may not have a well-developed individual interest for law study and thus may not be as receptive to constructive criticism as their professors expect. This situation highlights both the importance of considering students' phase of interest for law study in making decisions about the quantity and quality of feedback to give and the importance of helping students develop an interest for law study because students with a well-developed individual interest for law study will be most receptive to the type of constructive criticism that will enable them to further develop their knowledge and skills.

Thus, the research regarding interest that underlies the enthusiasm paradigm suggests both that students' phase of interest for law study should influence the quantity and quality of feedback that students receive and that positive feedback plays a crucial role in helping students develop an interest for law study.

The research regarding vitality also raises questions regarding the role of formative assessment in cultivating or inhibiting enthusiasm for law study. Feelings of competence have been correlated with vitality, ${ }^{271}$ and individuals who are told that they are performing a task that is a measure of intelligence report smaller increases in vitality than individuals who are focused on the task itself. ${ }^{272}$ Feedbackeven well-intentioned feedback-might undermine a student's feelings of competence, thereby diminishing that student's vitality regarding the study of law and resultant enthusiasm for law study. Moreover, students might interpret feedback as a measure of their intelligence or ability and might experience lower vitality than if those students focused on the task at hand.

The research regarding interest and vitality suggests that formative assessment should vary depending on students' level of enthusiasm for law study. If one of the goals of legal education is to cultivate law

270. Although students with a well-developed individual interest for law study may be receptive to constructive criticism, these students may still have a preference for the order in which they receive feedback. See id. at 123 (noting that students with a well-developed individual interest for writing prefer to get feedback regarding the content of their writing before getting feedback regarding their "technique"); $i d$. at 135.

271. See Ryan \& Frederick, supra note 23, at 560.

272. Nix et al., supra note 105 , at $277-78$. 
students' enthusiasm for law study, then formative assessment at the beginning of a student's law school career should be quite different from formative assessment towards the end of a student's law school career. Feedback at the beginning of law school should focus more on building students' confidence 273 and encouraging students to identify with their role as law students. As a law student progresses through law school, developing a well-developed interest for law study, feedback should become more and more focused on preparing that student for practice and giving that student more challenges so that the student can further develop and improve. ${ }^{274}$ For law professors who teach first-year students, these differing purposes of formative assessment require giving serious thought to how classroom exchanges are carried out, as well as how other forms of formative assessment (such as written comments on assignments) are given to students. Making the development of enthusiasm a priority of first-year formative assessment also requires giving serious thought to how much feedback is appropriate to give to first-year students, who might perceive wellintentioned constructive criticism as overwhelming and a threat to their developing identities as law students. ${ }^{275}$

Although law professors should not necessarily give students only the type and quantity of feedback that students want to receive, law professors should at least be mindful of the reception that their feedback is likely to get from their students and consider ways to provide

273. See Best Practices, supra note 2, at 73 ("Particularly given the intellectual demands of the skills and values law students are learning, law professors should sequence instruction so that students have early success and therefore build self-efficacy."). Best Practices defines "self-efficacy" as "'students' beliefs about whether they have the ability to successfully master an academic task." Id. at 72 (quoting Anastasia S. Hagen \& Claire Ellen Weinstein, Achievement Goals, Self-Regulated Learning, and the Role of Classroom Context, New DIRECTIONS FOR Teaching and Learning: Understanding Self-Regulated Learning, Fall 1995, at 43, 45). See generally Díaz et al., supra note 158 (examining, inter-alia, the relationship between first-year law students' self-efficacy and performance).

274. Once students have a well-developed individual interest, they require "challenges ... for [their] interest to continue and deepen." Putting Things into Words, supra note 29, at 137.

275. The enthusiasm paradigm suggests that professors should be particularly sensitive to first-year law students' receptivity (or lack thereof) to feedback, even if this means giving less feedback to students in order to help students develop positive feelings about law study. Although Best Practices advocates for more formative assessment in law school, Best Practices also recognizes that giving students large quantities of feedback may detract from, rather than contribute to, the effectiveness of that feedback. Best PRACTices, supra note 2, at 126-27 ("'Large quantities of feedback may be excessive, simply overwhelming students... [T] his may be particularly true of students who are struggling." (quoting Maranville, supra note 19, at 73)); see also London et al., supra note 10, at 476 (noting "students' doubts about their competence and intellectual ability [during the first year of] law school" and "that the way professors present ... feedback has important ramifications on [sic] whether students feel efficacious about their ability to be successful"). 
students with meaningful feedback that does not undermine students' enthusiasm for law study. ${ }^{276}$ In fact, if cultivating enthusiasm for law study is to be a goal of the first year of law school, then the desire to provide students with meaningful feedback should be informed, and likely tempered, by the concern with cultivating students' enthusiasm for law study. In the long run, however, cultivating students' enthusiasm for law study will enable students to be more receptive to feedback and better able to develop and improve. ${ }^{277}$

\section{B. Pedagogy}

In addition to examining assessment through the lens of the enthusiasm paradigm, the enthusiasm paradigm suggests other ways that law professors can create a learning environment for first-year law students that promotes their enthusiasm for law study. In fact, there are countless specific ways in which law professors can create an enthusiasm-promoting learning environment based upon the research underlying the enthusiasm paradigm. This Section addresses a few of these ways. ${ }^{278}$

According to the four-phase model of interest development, positive feelings about a subject or activity can cause interest to develop and deepen. ${ }^{279}$ At the early phases of interest, positive feelings play a particularly important role in the development and deepening of interest. ${ }^{280}$ If most first-year law students are, at best, at an early phase of interest for law study, then creating opportunities for students to experience positive feelings in connection with law study is particularly important. ${ }^{281}$

276. It is inevitable that students will receive feedback during their first semester of law school. For example, students receive feedback in their first-year legal analysis and writing courses. Preparing students to receive feedback and explaining the purposes of feedback can also help to cultivate student enthusiasm by diminishing negative feelings that students might feel upon receiving feedback. See Best Practices, supra note 2, at 176-77 (recommending that law professors "[t]rain students to receive feedback").

277. See Developing Interest for Writing, supra note 54, at 2-3 (stating that students with a well-developed individual interest for writing are receptive to feedback and want to improve their writing).

278. See infra notes 279-296 and accompanying text.

279. The Four-Phase Model of Interest Development, supra note 22, at 112.

280. Id. at 114.

281. Gerry Hess has advocated for the creation of "an effective teaching and learning environment" in law schools. Heads and Hearts, supra note 2, at 76 (emphasis omitted). Hess describes ways in which law teachers can promote learning in a constructive environment and identifies "eight components of an optimal classroom environment for legal education: respect, expectations, support, collaboration, inclusion, engagement, delight, and feedback." Id. In discussing "delight," Hess uses both the words "enthusiasm" and "passion." Id. at 104-05. In discussing the importance of "delight," both Hess and a student whose comments Hess includes in 
Moreover, the very time when it is most important to promote students' positive feelings about law study (when students are at the beginning of their law school career), is also the time when first-year law students are likely to be particularly susceptible to negative feelings about law study. Students at the earliest phase of interest development may lose interest when they are given work that is beyond their capabilities. ${ }^{282}$ In addition, students at the earliest phase of interest for an activity may find tasks regarding that activity to be laborious, ${ }^{283}$ further detracting from the positive feelings associated with that activity and impeding the development of interest for that activity. Students may feel particularly insecure about their competence at the beginning of law school, which may undermine both students' vitality and interest associated with law study. ${ }^{284}$

In a concerted effort to cultivate enthusiasm for law study, law teachers can focus on promoting their students' positive feelings regarding law study and minimizing their students' negative feelings about law study. ${ }^{285}$ One very concrete way to promote positive feelings regarding law study is to be very careful about the quantity of work that new law students are assigned. ${ }^{286}$ For example, teachers of first-year law students should be very mindful of the quantity of reading that first-year students are assigned. Teachers of first-year law students can also consult one another regarding the amount of work and

the article suggest a connection between interest and vitality. The student states that "I think the students lose that part of vitality of a subject when a professor seems to be not interested in the subject anymore. It's not refreshing to the professor, and when the students pick up on it, it's not refreshing to them as well." $I d$. at 104 . Hess notes that "[t]eachers can convey their enthusiasm for teaching and their passion for their subjects" by "[e]xplicitly describing [the teachers'] interest." Id. at 105. Hess explains that teachers should communicate their interest to students by "[t]ell[ing] students why you are energized by teaching this course." Id.

282. Developing Interest for Writing, supra note 54, at 14.

283. Putting Things into Words, supra note 29, at 123.

284. See Ryan \& Frederick, supra note 23, at 560; Putting Things into Words, supra note 29, at 123 (stating that students with a triggered situational interest for writing are "afraid of audience censure and being thought of as 'stupid"). But see Developing Interest for Writing, supra note 54 , at 14 (distinguishing between "the need to feel competent" and the need for tasks to "be doable," and noting that it is the latter that is important for students with a triggered situational interest for writing).

285. See Best Practices, supra note 2, at 110 (advocating for creating a positive learning environment for law students); see also Heads and Hearts, supra note 2.

286. See G. Andrew H. Benjamin, Alfred Kaszniak, Bruce Sales \& Stephen B. Shanfield, The Role of Legal Education in Producing Psychological Distress Among Law Students and Lawyers, 1986 Ам. B. Found. Res. J. 225, 248 (noting that many first-year law students "feel overwhelmed by the workload"); Glesner, supra note 9, at 655 (noting that "[p]erhaps the most threatening part of law school is the sheer amount of work required" and recommending that law student workloads be made more "manageab[le]"); Heads and Hearts, supra note 2, at 79 (noting the physical and psychological toll that the workload of the first year of law school can take on law students). 
deadlines for work of their first-year students so that, in the aggregate, the workload assigned to first-year students does not impede first-year students' development of interest for law study. ${ }^{287}$

From a more substantive perspective, law teachers can promote their students' enthusiasm for law study by giving their students opportunities to feel that their law study is personally meaningful. Students at all phases of interest want to "feel connected to their work" 288 and an individual's value for an activity is one component of an individual's interest in that activity. ${ }^{289}$ Law teachers could offer students different topics for study that are related to students' prior experiences before coming to law school or other interests that students have. ${ }^{290}$ Law teachers could also help students see connections between topics being studied and students' experiences and interests outside of law school. ${ }^{291}$

Another element of making students' studies personally meaningful could involve giving students choices about topics to study. Both interest and vitality can be promoted when individuals feel that they are engaged in an activity of their own choosing. ${ }^{292}$ Giving students choices about topics to study may not be a practicable option in all

287. Although the cultivation of student enthusiasm is one priority influencing students' workloads, it is not the only concern. Law professors, particularly in first-year courses, may feel pressure to cover a large amount of material in a relatively short period of time. Moreover, law schools may prepare students for practice by requiring students to manage multiple commitments (for example, by balancing the workload of all of their classes). See Glesner, supra note 9 , at 655 ("[C]aseload pressures are an inherent part of today's competitive legal climate."). However, these concerns are not irreconcilable. While the quantity of work assigned to law students should be carefully considered, the enthusiasm paradigm does not require that the first year of law school not be challenging for law students. However, the first year of law school-and subsequent years-should be appropriately challenging. The research underlying the enthusiasm paradigm highlights both that first-year students may find assignments even more challenging than their professors anticipate and the negative consequences of giving assignments that are too challenging for first-year students. $C f$. id. (distinguishing law practice from law school and noting that "[b]y addressing not only the amount of work we require of our students, but also the way in which we guide them in that work, we can significantly improve their future ability to work hard and well").

288. Developing Interest for Writing, supra note 54, at 13.

289. The Four-Phase Model of Interest Development, supra note 22, at 112.

290. See Heads and Hearts, supra note 2, at 99 (recommending that law professors "increase students' motivation and improve their learning by finding out about their backgrounds, interests, and experiences and using that information when designing learning activities"); see also Barbara Glesner Fines, The Impact of Expectations on Teaching and Learning, 38 Gonz. L. Rev. 89, 127 (2002-2003) (recommending that law professors take "student interest and enthusiasm" into account in selecting course topics).

291. Heads and Hearts, supra note 2, at 99.

292. See Putting Things into Words, supra note 29 , at 127,133 (noting that students at certain phases of interest for writing prefer being given choices); Nix et al., supra note 105, at 280-81; see also Ryan \& Frederick, supra note 23, at 553, 555, 559-60. Sheldon and Krieger's research also found correlations between law students' perceived autonomy support and psychological need 
situations but could be utilized when possible. ${ }^{293}$ First-year students may not know enough about the law to feel able to make their own choices about topics to study. Also, teachers may not feel that they can offer quite so much flexibility regarding the curriculum. However, teachers could offer students some options regarding topics to study and assign projects to students where students either could completely choose their own topics or choose their own topics from among a list of different options supplied by the teacher. ${ }^{294}$ Another way to give first-year students some choice in the context of an established curriculum would be to let students choose the topics for which they will be called on in class. ${ }^{295}$

Thus, law professors can cultivate students' enthusiasm for law study by promoting students' positive feelings for law study and helping students to find personal meaning in law study. ${ }^{296}$

\section{Curriculum}

In addition to influencing the learning environment within individual classes, the enthusiasm paradigm raises questions about the law school curriculum. Two specific questions that the enthusiasm para-

satisfaction, self-determined career motivation, and subjective well-being. Understanding the Negative Effects, supra note 12 , at $890,894$.

293. See Glesner, supra note 9, at 657 (recommending that law students be given "choices as to projects or programs to pursue" and that explanations be provided to students when choice is not an option).

294. More generally, "collaborative course design," where students participate in certain elements of course design, can be a way to promote personally meaningful law study and law student autonomy. Heads and Hearts, supra note 2, at 97; accord Gerald F. Hess, Collaborative Course Design: Not My Course, Not Their Course, but Our Course, 47 WAShBURn L.J. 367 (2008) [hereinafter Collaborative Course Design]; see also Best PRACTICEs, supra note 2, at 121 (discussing the value of student participation in course design). First-year students, however, may not be ready to participate in all aspects of course design. See Collaborative Course Design, supra, at $379 \&$ n.119 (noting that first-year students may be able to participate in some, but not all, aspects of course design).

Giving students personally meaningful choices also requires that teachers learn about their students. Demonstrating a concern with getting to know students and then offering students meaningful choices that demonstrate an appreciation for students' preferences might itself serve to promote students' interest in law study. See Heads and Hearts, supra note 2, at 99 (recommending that professors get to know their students and take their students' "backgrounds, interests, and experiences" into consideration in their courses).

295. Giving students some control and predictability over when they will be called on in class might also alleviate stress and contribute to a positive learning environment, thereby further fostering student enthusiasm.

296. There are other aspects of law school pedagogy that are worth reconsidering through the lens of the enthusiasm paradigm. For example, although peer feedback is sometimes used as an example of a positive teaching and learning technique, Lipstein and Renninger's research suggests that the effectiveness of this technique may vary depending on students' phase of interest. Compare CARNEGIE REPORT, supra note 1, at 119-20, with Interest for Writing, supra note 69, at $80-81$. 
digm raises regarding the law school curriculum are whether students should be able to choose at least one elective course during their first year of law school and whether students should be required to take an Introduction to Legal Education course during their first year of law school. Although these questions may seem somewhat contradictory, one giving students the opportunity to choose a course and one requiring students to take a specific course, they both relate to the cultivation of law students' enthusiasm for law study.

\section{Elective Courses}

The enthusiasm paradigm suggests that one way to cultivate students' enthusiasm for law study would be to give students the opportunity to choose at least one of their courses during their first semester of law school. In general, most first-year law students take a fixed set of courses during their first year of law school. ${ }^{297}$ First-year law students' enthusiasm for law study might, however, be better cultivated if first-year law students were able to choose at least one of their courses during their first semester of law school.

Enabling first-year students to choose at least one course during their first semester of law school could help students feel a stronger connection to the study of law. Students at all phases of interest want to "feel connected to their work," 298 and both interest and vitality can be promoted when individuals feel that they are engaged in an activity of their own choosing. ${ }^{299}$ A student might feel more connected to the study of a topic that he or she chose to study both because the student feels a personal connection to the topic itself (resulting in the student's choice of the particular course) and by virtue of the fact that the student chose the course rather than having the course required by the law school.

Moreover, giving first-year students a menu of courses to choose from and enabling first-year students to choose at least one course

297. CARnegie Report, supra note 1 , at 63 ; see also AALS Committee on Curriculum, SURVEY OF INNOVATIONS IN LAW SCHOOL CuRRICUla, http://www.aals.org/documents/curriculum/Survey.pdf (last visited Apr. 28, 2009) (reporting that nineteen law schools responded that they had "an elective in the first year," and eighty-three law schools responded that they did not have "an elective in the first year"). For those first-year students who are able to choose an elective, this choice may not be available until the second semester of the first year. Id.

298. Developing Interest for Writing, supra note 54, at 13.

299. See Putting Things into Words, supra note 29, at 127, 129, 133 (observing that students with a triggered situational interest and an emerging individual interest for writing preferred being given freedom of choice regarding their writing assignments, although students with a maintained situational interest preferred more guidance from the teacher); Nix et al., supra note 105 , at 280-81 (discussing the relationship between autonomy and vitality); see also Ryan \& Frederick, supra note 23 , at 553, 555, 559-60. 
during their first semester of law school could accelerate the cultivation of interest for law study because it would take advantage of interest that the students might already have for a particular topic of study. A student who chooses to take a particular course from among a choice of courses might at least have a triggered situational interest in the topic of that course. ${ }^{300}$ Although the student may not know much about the topic, something about that course has triggered the student's interest to the extent that the student has chosen to take that course from among a choice of courses. ${ }^{301}$ This triggered situational interest could provide the foundation for the deepening of the student's interest. ${ }^{302}$ In addition, a student who chooses to take a particular course may already have a level of interest beyond a triggered situational interest in the course and, therefore, be drawn to learning more about the topic of that particular course. ${ }^{303}$

Of course, giving students the opportunity to choose at least one course during the first semester of their first year of law school means that law schools must provide a menu of courses for their students to choose from. For most law schools, this would require modifying the first-year curriculum to both make room in the students' schedule for the elective course and provide a selection of courses for students (with faculty to teach those courses). In addition, incoming first-year students may not feel equipped to choose between a selection of courses, so law schools may need to provide some advising for students to help students make their course choice. ${ }^{304}$

300. The Four-Phase Model of Interest Development, supra note 22, at 114.

301. Id.

302. $I d$.

303. Id. at $114-15$.

304. Another option would be for law schools to give students the choice of whether to take an elective course during their first semester of law school. That way, if a student did not feel comfortable choosing a course, the student would not be forced to make that choice. This process might, nonetheless, promote student enthusiasm because it would add an element of autonomy to the "required" first-year curriculum: students who ended up taking all of the ordinarily required first-year courses would have made the choice to do so. See Suzanne C. Segerstrom, Perceptions of Stress and Control in the First Semester of Law School, 32 Willametre L. Rev. 593, 598 (1996) ("It should be noted that the perception of control, in some cases, may be as important as actual control. Many of the negative effects of uncontrollable stressors are ameliorated when a person ... is given an option to exert control, even if this option is not exercised.").

Another issue regarding offering first-year law students a choice of courses is whether those electives should be for first-year students only or whether first-year students should take classes along with second- and third-year law students. It would likely be easier administratively to have first-year students take courses with upper-level students because then additional electives for only first-year law students would not have to be developed. In addition, taking courses with upper-level students might benefit some first-year students. Taking classes with upper-level students might provide first-year students who have a well-developed individual interest for the topic of study (or for law study generally) the challenge that they need for their "interest to 
Nonetheless, the benefits of providing students choice during the first semester of their first year of law school may well outweigh the administrative burdens. If students are not given the opportunity to choose a course during the first semester of their first year of law school, students may begin their study of law with no enthusiasm for their courses: no interest (even a triggered situational interest) and no vitality. ${ }^{305}$ Therefore, enabling first-year students to choose at least one of their courses during their first semester of law school can give law schools a head start in cultivating their students' interest for law study because students are given the opportunity to build upon an existing interest and exercise choice over at least one of their topics of study.

\section{Required Introduction to Legal Education Course}

In addition to giving students the option to choose a course during the first semester of their first year of law school, law schools could also cultivate students' enthusiasm for law study by offering a course that is specifically designed to cultivate students' enthusiasm for law study. The goals of this course would be to help students find personal meaning in law study, promote students' positive feelings for law study, and increase students' knowledge about and value for law study. ${ }^{306}$

One way to package this course would be as a required first-semester, first-year Introduction to Legal Education course, which would address the evolution of legal education, the design of legal education, critiques of legal education, and the connection between legal educa-

continue and deepen." Putting Things into Words, supra note 29, at 137 (stating that for a student with a well-developed individual interest for writing, "[c]ontinued challenges in writing are essential for [that student's] interest to continue and deepen"). On the other hand, for some first-year law students, taking classes with upper-level students might have negative consequences for enthusiasm: for example, by undermining first-year students' feelings of competence and thereby impeding their vitality. See Ryan \& Frederick, supra note 23, at 559-60 (reviewing the literature regarding the relationship between vitality and competence).

305. The mere fact that first-year law students have chosen to apply to and attend law school may indicate that students have a triggered situational interest regarding some aspect of law school, but it does not mean that students necessarily have a triggered situational interest for law study or for the particular courses that ordinarily comprise the first-year law school curriculum. A law student may have chosen to attend law school because of a desire to put off entering the job market or to gain a professional degree, reasons that may have no bearing on a student's interest for (or vitality associated with) law study. Moreover, a less-developed interest for some aspect of law school (or law practice) is, on its own, unlikely to sustain itself or give rise to a more-developed interest through the first year of law school.

306. See The Four-Phase Model of Interest Development, supra note 22, at 114 (identifying "positive feelings," "knowledge," and "value" as the components of interest). 
tion and law practice..$^{307}$ In examining these topics, students would learn more about the context and rationale for their study of law, and students would have a dedicated forum for exploring and discussing their experiences in law school.

By giving students an understanding of legal education, the Introduction to Legal Education course could promote students' interest for law study. ${ }^{308}$ In addition, the Introduction to Legal Education course could promote students' positive feelings for law study by helping students both identify the value of legal education to them ${ }^{309}$ and anticipate some of the frustrations that they might face in connection with law study. Moreover, enabling students to find value and personal meaning in law study could enable students to feel that law study was the product of their own choice and this sense of autonomy would promote students' vitality regarding law study. ${ }^{310}$

307. Offering this course as a full-semester course during the first year of law school would give the course the status of a full-fledged law school course and would enable first-year students to engage in the course as they progress through their first semester of law school. However, it might be difficult to integrate an additional course into the first semester of law school from both the students' and law school's perspectives. The value of the course for the students might be undermined if the students are overwhelmed by the additional course, and it might be logistically difficult to add a full course to the first semester of law school. One alternative to the firstsemester course model would be to include an Introduction to Legal Education component during first-year orientation and then have a series of meetings throughout the first semester that would build upon the introduction to the topic at orientation and give the students the opportunity to reflect on their experiences as they progress through the first semester of law school.

Another option would be to offer the course as one of the electives that first-year students could choose to take during their first semester of law school. Of course, the benefit of requiring the course is that it would ensure that all first-year students participated in the course.

308. See Putting Things into Words, supra note 29 , at 138 (noting that helping students develop a greater understanding of writing may help students deepen their interest for writing). Most law students enter law school with not only little knowledge about the law but also little knowledge about legal education. As a result, students may not understand the pedagogy used in law school and may, in fact, misunderstand the pedagogy used in law school, leading to feelings of frustration and incompetence and impeding the development of enthusiasm for law study. See Peggy Cooper Davis \& Elizabeth Ehrenfest Steinglass, A Dialogue About Socratic Teaching, 23 N.Y.U. Rev. L. \& Soc. Change 249, 271-72 (1997) (stating that students' lack of understanding about the Socratic method-and professors' failure to explain the Socratic method-may undermine the effectiveness of the Socratic method and lead students to "experience sequences of Socratic questions as an indication that they have not answered adequately and do not have the necessary capacities").

309. The importance of helping students develop value for law study is also consistent with self-determination theory's constructs of intrinsic motivation and identified motivation. See supra note 170 . If students value law study, then they might be intrinsically motivated to study law (studying law for its own sake). Even if students are not intrinsically motivated to study law, however, valuing law study could promote students' identified motivation for law study (engaging in law study because law study is important).

310. See Ryan \& Frederick, supra note 23, at 553, 555, 559-60; Nix et al., supra note 105, at 280-81. 
Thus, a first-semester Introduction to Legal Education course could provide an opportunity for students to develop enthusiasm for law study during their first semester of law school and lay the groundwork for the remaining semesters of law school. ${ }^{311}$

\section{CONClusion}

The enthusiasm paradigm provides a new lens through which to examine legal education, particularly the first year of law school, a crucial time during which enthusiasm for law study can be developed. ${ }^{312}$ The enthusiasm paradigm provides a way to define and examine law student enthusiasm and identify those aspects of legal education that cultivate or impede law student enthusiasm. The enthusiasm paradigm also identifies the cultivation of law student enthusiasm for law study as an explicit priority of legal education, particularly during the first year of law school. Legal education may well presume that stu-

311. Some law schools do offer courses in which students can learn about and reflect upon legal education, but these courses are typically upper-level electives and their purpose is not necessarily to cultivate law students' enthusiasm for law study. See Carnegie Report, supra note 1, at 155 (describing Daisy Floyd's course on Advanced Legal Ethics at Mercer Law School, which "directly addresses issues of meaning, professional identity, and quality of life in law school and in legal practice... [in order] to mitigate law schools' potential negative effects on lawyers' sense of purpose"); Heads and Hearts, supra note 2, at 111 (briefly discussing the author's experience teaching "a seminar on legal education to twelve upper-level students, most of them in the second semester of their third year").

Law schools may be more likely to incorporate an introduction to the legal profession, rather than an explicit introduction to legal education, into the first year of law school. See, e.g., Does Legal Education, supra note 2, at 276 (noting that one of the schools studied "require[d] firstyear students to attend several offerings in its Perspectives on the Legal Profession program, which includes topics of well-being, depression, substance abuse, and professional values"); $c f$. CARnegie Report, supra note 1, at 152-53 (describing a first-year engineering course at the University of Michigan, Introduction to the Engineering Profession, which, inter alia, "is intended to help students understand the nature of engineering work and to generate enthusiasm and a sense that they belong in the field").

Sheldon and Krieger did not directly examine the relationship between the Perspectives on the Legal Profession program and students' changes in well-being and motivation in law school. Does Legal Education, supra note 2; see also Understanding the Negative Effects, supra note 12. However, Sheldon and Krieger found that students at the school that had this program still "evidenced strong declines in positive affect, life satisfaction, and aggregate [subjective wellbeing], as well as strong increases in negative affect." Does Legal Education, supra note 2, at 278. In addition, the students at this school "reported significantly less intrinsic motivation [towards the end of their first year of law school], i.e. less sense of being motivated by enjoyment and interest" and "very strong increases in [their] introjected motivation for being in law school, i.e. their sense of being motivated by guilt and anxiety." Id. However, unlike the law students at the other school studied, these law students "reported somewhat more identified motivation [towards the end of their first year of law school], i.e. a sense that the goal is personally important to them." Id. at 279.

312. Although this Article focuses on enthusiasm for law study, the enthusiasm paradigm also provides a framework for understanding and assessing students' and lawyers' enthusiasm for law practice. See supra note 9. 
dents enter law school with more enthusiasm for law study than they actually have: with a more developed interest for law study and with more vitality associated with law study than they actually have. Legal educators must ask whether legal education is designed for students who already have enthusiasm for law study, leaving those students who come to law school without such enthusiasm to suffer the consequences. Rather than presuming that students enter law school with enthusiasm for law study, legal education should focus on the cultivation of students' enthusiasm for law study.

The enthusiasm paradigm also reinforces the need for further research regarding law students. ${ }^{313}$ Specifically, research is needed regarding incoming first-year law students' enthusiasm for law study and whether that enthusiasm is, in fact, cultivated or impeded during the course of students' time in law school. In addition, research is needed regarding specific aspects of law school pedagogy and curriculum design in order to identify particular features that promote or inhibit students' enthusiasm for law study. ${ }^{314}$ Other disciplines rely on evidence from research studies to inform their practice; ${ }^{315}$ legal educa-

313. Both Sheldon and Krieger and the Carnegie Report recognize the need for additional research regarding legal education. Understanding the Negative Effects, supra note 12, at 895; CARNEGIE RePORT, supra note 1, at 19; see also London et al., supra note 10, at 456 (noting the need for "committed programs of evaluation, experimentation and intervention in the legal education system"). See generally James R.P. Ogloff, David R. Lyon, Kevin S. Douglas \& V. Gordon Rose, More Than "Learning to Think Like a Lawyer:" The Empirical Research on Legal Education, 34 CREIGHTON L. REv. 73 (2000) (noting the relative lack of empirical research regarding legal education, reviewing and critiquing existing empirical research regarding legal education, and recommending ways to improve empirical research regarding legal education). Particularly because the enthusiasm paradigm is based upon an existing foundation of psychology theory and research (regarding interest and vitality), the enthusiasm paradigm points to specific avenues for research regarding law students' enthusiasm for law study. Research regarding law students' interest for law study would also add to the existing body of research regarding the four phases of interest development, which has focused on younger students' interest for writing. See Putting Things into Words, supra note 29, at 119; Developing Interest for Writing, supra note 54 , at 2 . Research regarding law students' interest for law study would also enable comparison between the traits of law students at different phases of interest for law study and students at different phases of interest for writing, as identified by Lipstein and Renninger. See generally Putting Things into Words, supra note 29.

314. Aspects of law school pedagogy and course design regarding which research is needed include: quantity of summative assessment; method of summative assessment (pass/fail, grades, different grading systems); first-year Introduction to Legal Education course, and first-year elective courses.

315. For example, within the medical field, "[e]vidence-based medicine is the conscientious, explicit and judicious use of current best evidence in making decisions about the care of individual patients." CEBM: Centre for Evidence Based Medicine, http://www.cebm.net/index.aspx?o $=1014$ (last visited Apr. 28, 2009). Similarly, within the field of architecture, "[e]vidence-[b]ased [d]esign is the process of basing decisions about the built environment on credible research to achieve the best possible outcomes." The Center for Health Design, Definition of EvidenceBased Design, http://www.healthdesign.org/aboutus/mission/EBD_definition.php (last visited 
tion too should be more informed by research in making decisions about curriculum design and pedagogy. ${ }^{316}$

Recent critiques of legal education have recommended that law schools be better environments for law students. ${ }^{317}$ One way to make law schools better environments for law students is by helping students develop enthusiasm for law study. Law schools should not presume that students enter law school with enthusiasm for law study; law schools should purposefully cultivate their students' enthusiasm for law study. The enthusiasm paradigm provides a better understanding of law student enthusiasm and ways in which legal education can both assess and, most importantly, cultivate law student enthusiasm.

Apr. 28, 2009). Similarly, there should be more evidence-based curriculum design and pedagogy in legal education. This would, necessarily, require research that could inform such curriculum design and pedagogy.

316. In fact, there have been calls for research in legal education to inform reforms of legal education. See Understanding the Negative Effects, supra note 12, at 895; London et al., supra note 10, at 456 (noting the need for "programs of evaluation, experimentation and intervention in the legal education system"); Gulati et al., supra note 2, at 260 n. 41 ("There is an extensive literature on proposals to reform legal education. What is missing in much of this literature, however, is a link to rigorous research on what exactly the problems with law school are."); see also CARNEGIE REPORT, supra note 1, at 19 (suggesting the need for further research and scholarship regarding the pedagogy of legal education); Glesner Fines, supra note 139, at $912 \mathrm{n} .199$ ("Much of the structure and methods of legal education [have] never been systematically described or tested.").

317. See, e.g., Best Practices, supra note 2, at 285. 
